\title{
Hydrodynamic characterization of the bottom boundary layer in a coastal upwelling system (Ría de Vigo, NW Spain)
}

N.Villacieros-Robineau $^{1 \mathrm{a}^{*}}$, J.L. Herrera $^{2 \mathrm{~b}}$, C.G.Castro $^{1 \mathrm{c}}$, S.Piedracoba $^{2 \mathrm{~d}}$, G.Roson $^{2 \mathrm{e}}$,

${ }^{1}$ Instituto de Investigacións Mariñas, Consejo Superior de Investigaciones Científicas, Eduardo Cabello 6, Vigo, 36208, Spain

${ }^{2}$ Grupo de Oceanografía Física de la Universidade de Vigo, Lagoas-Marcosende S/N, Vigo, 36310, Spain.

anvrobineau@iim.csic.es ; ${ }^{\mathrm{b}}$ cortijo@uvigo.es; ${ }^{\mathrm{c}}$ cgcastro@iim.csic.es;

d $\underline{\text { spiedra@uvigo.es; }}$; groson@uvigo.es

* Corresponding author.

Tel: +34 986231930, fax: +34986292762

E-mail address: nvrobineau@iim.csic.es (N.Villacieros-Robineau). 


\begin{abstract}
The hydrodynamics of the bottom boundary layer (BBL) in the Ría de Vigo (NW Iberian Peninsula) are studied for the first time, identifying their possible forcing factors and filling a previous lack of knowledge about the coastal upwelling system of NW Iberian Peninsula. For tackling this subject, high resolution time series of bottom currents by means of a downwards looking Acoustic Doppler Current Profiler (3 meters above the bottom) were recorded in the inner part of the Ría de Vigo covering the four seasons of the climate year $2004-2005$.
\end{abstract}

Our results point to a coupling among bottom residual currents, shelf winds and runoff supporting previous works not directly focused on BBL. Most of the time, $64.5 \%, 75.4 \%$ and $61.6 \%$ for residual, tidal and total currents respectively, the bottom currents respond to a logarithmic profile being possible to apply the law of the wall and estimate shear stress.

Shear stress variability is controlled by the frequency of wind reversals and modulated by runoff and thermal stratification. Rapid shifts of wind direction favors the generation of shear stress. Intense summer stratification or strong winter mixing of the water column reduces shear stress levels. Runoff by increasing the variability of the velocity pulse direction can favor the development of shear stress. Bottom shear stress reaches levels that are strong enough ( $\sim 5 \%$ of the time in autumn) to re-suspend fine cohesive sediments. This fact comes out to support previous biogeochemistry studies suggesting the occurrence of intense resuspension processes during the autumn season.

Key words: bottom boundary layer, bottom shear stress, resuspension, coastal upwelling and Ría de Vigo. 


\section{Introduction}

Coastal regions are among the most biogeochemically active areas of the biosphere (Jickells, 1998). Since they are natural boundaries among terrestrial, oceanic and atmospheric ecosystems, they are exposed to intense gradients of energy and matter. In fact, one of the inherent characteristics of coastal systems, in contrast to oceanic ones, is the interaction / proximity to sediments. The exchange of carbon and nutrients between surface sediment and water column in these regions is directly linked to their high primary production and export of material and energy to the adjacent ocean (Joint and Wassmann, 2002). In coastal regions, the bottom boundary layer (BBL) plays an important control over the dynamics and biogeochemistry of these ecosystems. The BBL constitutes the portion of water column where the distribution of its properties and processes is directly affected by the presence of the sediment - water interface (Boudreau and Jorgensen, 2001). The highest dissipation of energy from currents, waves and turbulence occurs in the BBL (Boudreau and Jorgensen, 2001). Besides, it is in the $\mathrm{BBL}$ where the most intense diagenesis of settling material takes place and consequently is characterized by an intense biogeochemical activity. Detailed investigations of BBL have been carried out at several coastal margins (Stenberg et al., 1986; Towsend et al., 1992; Thomsen, 2002). Unfortunately, there are other systems as the Rías Baixas (NW Iberian Peninsula) where this subject has not received much attention.

The Ría de Vigo (Figure 1), one of the five Rías Baixas (NW Iberian Peninsula), is located within the northern boundary of the NW Africa coastal upwelling system (McClain et al., 1986). At these latitudes $\left(37^{\circ}-43^{\circ} \mathrm{N}\right)$ shelf winds follow a seasonal pattern associated to the large-scale climatology of the NE Atlantic. Upwelling- 
favorable northerly winds predominate from March-April to September-October in response to the seasonal migration of the Azores High. In the opposite case, downwelling favorable southerly winds prevail the rest of the year (Wooster et al., 1976; McClain et al., 1986; Blanton et al., 1984). These upwelling and downwelling events are the principal oceanographic phenomena that control the residual circulation pattern in the Ría generating a classical 2D estuarine circulation pattern in the inner part of the Ría and a more complex 3-D scheme in the outer part (Souto et al., 2003; Gilcoto et al., 2007). River discharge also affects this pattern, modulating its response through the buoyancy forcing. Other factors, such as tides and wave - climate (swell and sea waves) have not been well studied to date.

The residual circulation in the Ría de Vigo has been studied since the 80's starting with stationary theories based on classical gravitational (baroclinic) models (Prego et al., 1990). From this, the non-stationary models were imposed and different forcings such as remote winds (Garvine, 1985) and runoff influence (Garvine et al., 1992) were included. In the last decades, efforts to study the circulation in the Rías Baixas were centered on the application of box models (Rosón et al., 1997; Álvarez-Salgado et al.,2000; Piedracoba et al., 2005; Gilcoto et al., 2007), numerical models (Taboada et al., 1998; Montero et al., 1999; Torres-López et al.,2001; Souto et al., 2003) and acquisition of in-situ data (Míguez et al., 2001; Piedracoba et al., 2005 ; Souto et al., 2003 and Gilcoto et al., 2001). Unfortunately, bottom currents have not been characterized yet due to lack of near sea bottom data. The existing studies about bottom currents were done with numerical model approaches such as HAMSOM finite difference simulation model (Diz et al., 2004). However, other studies tackling the water column biogeochemistry (Prego et al., 1995; Nieto-Cid et al., 2005; AlonsoPérez et al., 2010), spatial variability of sediment diagenesis (Rubio et al., 2000; Rey et 
al., 2005; Mohamed et al., 2011), benthic species distribution (Diz et al., 2004) and sediment distribution (Vilas et al., 2005 and Quelle et al., 2011) point to the key role played by BBL dynamics showing that there is an urgent need for understanding the dynamics of the BBL in this coastal upwelling affected system.

Our study is integrated into the FLUVBE (Coupling of vertical and benthic fluxes in the Ría de Vigo) project where other aspects of the water column biogeochemistry have been analyzed (Arbones et al., 2008; Zúñiga et al., 2011). The aim pursued in this manuscript is to get a first insight into the dynamics of the BBL in the Ría de Vigo and their dependence on the oceanographic conditions through the analysis of their effects over sea bottom dynamics, particularly on resuspension processes.

\section{Materials and methods}

\subsection{Sampling program and measured variables}

From April 2004 till February 2005, four sampling cruises were carried out at the inner part of Ría de Vigo (Figure 1). The sampling strategy included a mooring deployment (Figure 2) with a downward looking ADCP (Acoustic Doppler Current Profiler) mounted on a tripod three meters above the bottom (mab) and a chain of seven or eight thermistors, depending on sampling period. There were a total of four cruises; spring (April $21^{\text {st }}-$ May $\left.6^{\text {th }} 2004\right)$; summer (July $\left.8^{\text {th }}-30^{\text {th }} 2004\right)$; autumn (October $8^{\text {th }}-$ November $14^{\text {th }} 2004$ ) and winter (January $18^{\text {th }}-22^{\text {th }} 2005$ ). The mooring deployment was located at the inner part of Ría de Vigo $\left(42^{\circ} 15.870^{\prime} \mathrm{N}, 8^{\circ} 42.132^{\prime} \mathrm{W}\right.$, Figure 1) over the central axis of the Ría and at approximately 20 m depth (FLUVBE Station). 


\subsection{Residual, tidal and total current and bottom shear stress}

The principal source of data is the ADCP measurements from which two variables were derived: residual current and tidal current. The ADCP was a RDI Workhorse 1200 $\mathrm{kHz}$ operating with an averaged time of $15 \mathrm{~s}$, 1s per ping, a blanking distance of $0.18 \mathrm{~m}$ and a vertical bin size of $0.1 \mathrm{~m}$.

The residual current has been extracted filtering the hourly averaged ADCP series with an $\mathrm{A}_{24}{ }^{2} \mathrm{~A}_{25}$ Godin filter (Godin, 1972) with a cutoff period of 30 hours in order to obtain the subtidal current values.

The tidal current has been calculated using an additional filter. First, it has been applied a Godin high-pass filter $\mathrm{A}_{1}^{2} \mathrm{~A}_{1.7}$ to the original $\mathrm{ADCP}$ series and then, the residual current has been subtracted from this filtered series. The result is a band-pass filtered series. The next step has been to apply the MATLAB@ tidal analysis package ttide (Pawlowicz el al., 2002) to each vertical level of the band pass filtered velocity to calculate the astronomical harmonic components. This has been done for each period separately except for spring. Only the significant harmonic components were considered to reconstruct the astronomical tidal velocity of each level. Since the spring period does not have enough days, the significant harmonics extracted from the joint analysis of the four periods have been applied. The number of significant harmonics and the explained variance of each analysis (for the layer $1.15 \mathrm{mab}$ ) are shown in Table 1.

Three data series (residual, tidal and total) have been used to obtain the seabed shear stress by applying the law-of-the-wall through the logarithmic profile method. The nearbed current profile can be expressed by the following logarithmic-layer model:

$$
U(Z)=\left(\frac{U_{*}}{k}\right) \ln \left(\frac{Z}{Z_{0}}\right),
$$


Where $U$ is the mean velocity, $Z$ is the height above the seabed, $U *$ is the shear velocity, $k$ is the von Karman constant $(0.4)$, and $Z_{0}$ is the bottom roughness length scale. The slope $U_{*} / k$ and intersection $\left(Z_{0}\right)$ are obtained by linear regression (Kundu et al., 2002).

The least-squares method was used for the logarithmic fit of residual speed profiles every $60 \mathrm{~min}$, to tidal speeds profiles averaged every $10 \mathrm{~min}$ and to total speeds every $15 \mathrm{~s}$, based on the orthogonal form of equation (1):

$$
Z=Z_{0} e^{\left(\frac{k}{U_{*}} U(z)\right)} ; \tau_{0}=\rho U_{*}^{2} \quad,(2)
$$

The variables obtained, shear velocity $\left(U_{*}\right)$ and bottom shear stress $\left(\tau_{0}\right)$, provide information on the dynamic conditions at the interface with the seabed and are commonly used as bases of calculation to quantify the possible resuspension of particles from the bottom.

\subsection{Temperature profiles and contours}

A chain of 7 thermistors ( 8 for autumn) and pressure sensors have been used for characterizing the water column thermal stratification (Figure 2). The vertical distribution of these sensors was established to cover the whole water column, from 1 meter below sea surface to 1-2 meters above seabed. The sampling frequency was 1 minute and the time series were filtered with an $\mathrm{A}_{24}^{2} \mathrm{~A}_{25}$ Godin filter (Godin, 1972) to obtain the residual component. Finally, these filtered data were interpolated linearly to plot the temperature contour (Figures 3 to 6). 


\subsection{Shelf winds and Upwelling Index}

Shelf winds during the study year were available for the Seawatch buoy off Cape Silleiro (Figure 1), belonging to Puertos del Estado (www.puertos.es) located at $42^{\circ}$ $7.2^{\prime} \mathrm{N},-9^{\circ} 25.8^{\prime} \mathrm{W}$ (at a depth of $523 \mathrm{~m}$ ). From these data, hourly values of Upwelling Index $\left(U I, \mathrm{~m}^{3} \mathrm{~s}^{-1} \mathrm{~km}^{-1}\right)$, were calculated following Wooster et al. (1976),

$$
U I=-\frac{\rho_{\text {air }} \cdot C_{D} \cdot|V| \cdot V_{y}}{\rho_{s w} \cdot f}, \text { (3) }
$$

Where $\rho_{\text {air }}$ is the density of air, $1.22 \mathrm{~kg} \mathrm{~m}^{-3}$ at $15^{\circ} \mathrm{C} . C_{D}$ is an empirical drag coefficient (dimensionless), $1.3 \times 10^{-3}$ according to Hidy (1972); $f$ is the Coriolis parameter at $42^{\circ}$ latitude; $\rho_{S W}$ is the density of sea water, $1025 \mathrm{~kg} \mathrm{~m}^{-3}$; and $|V|$ and $V_{y}$ are the wind speed and the north component of wind velocity recorded at the Seawatch buoy off Cape Silleiro.

\subsection{Runoff}

Continental runoff into the inner part of Ría de Vigo is a combination of regulated and natural flows. Daily flows were provided by the company in charge of the management of urban waters. The Eiras reservoir controlled $23 \pm 12 \%$ of the total flow of the River Oitavén-Verdugo during the study year 2004-2005. The natural component of the flow per unit area $\left(\frac{Q_{R}}{A}\right.$ in $\left.1 \mathrm{~m}^{2} \mathrm{~d} 1\right)$ was calculated according to the empirical equation of Ríos et al. (1992) from the daily precipitation in the drainage basin, $P(n)$,

$$
\frac{Q_{R}}{A}=\frac{1-k}{k-k^{30+1}} \sum_{n=1}^{30} P(n) k^{n},(4)
$$


This equation accounts for the influence of precipitation during the 30 days before the study date. The retention constant $k$ has a value of 0.75 (with a lag time of 16 days) for the $586 \mathrm{~km}^{2}$ drainage basin of the Ría de Vigo (Ríos et al., 1992). River discharge data were not filtered, as they came in the form of daily average values.

\subsection{Wave series}

Wave characterization at the shelf near the Ría de Vigo has been done using the available data from WANA hindcast reanalysis point $3014003\left(42.13^{\circ} \mathrm{N},-8.92^{\circ} \mathrm{W}\right.$, Figure 1). These data have been provided by Puertos del Estado (www.puertos.es). Waves from the southwest (third quadrant S-W) are the ones that most affect the inner zone of the Ría.

\subsection{Statistical analysis}

In order to analyze the obtained results two statistical methods has been applied: Mean regime and Empirical Orthogonal Functions (EOF).

The mean regime, applied to wind speed, current speed and shear stress, allows the extraction of average conditions for a given percentile of probability. In this way, it can be described the average conditions by the $50 \%$ percentile that represents the value exceeded $50 \%$ of the time. Another relevant parameter is the $95 \%$ percentile as it gives information about more energetic conditions, which define the most intense events.

EOF analysis, given a dataset of $\mathrm{n}$ dimensions (variables), returns a set of $\mathrm{n}$ orthogonal dimensions (statistical modes) ordered by explained variability (Preisendorfer and Mobley, 1988). Often, these modes match underlying natural processes in the data and here are used to describe correlations among bottom currents, 
temperature differences between the bottom and surface temperature $\left(\Delta \mathrm{T}_{\mathrm{BS}}\right)$ and acrossshelf Ekman transport (UI).

\section{Results}

\subsection{Oceanographic conditions during the sampling periods}

During the spring cruise (Figure 3), there were three episodes of significant wind strength. The first one, beginning on April $21^{\text {st }}$ was characterized by southerly winds, and the second and third episodes (between April $27^{\text {th }}-29^{\text {th }}$ and May $4^{\text {th }}-6^{\text {th }}$ respectively) by prevailing northerly winds. The $50 \%$ percentile of mean wind regime for the spring period was $6.7 \mathrm{~cm} \cdot \mathrm{s}^{-1}$. The temperature contour showed a deepening of the isotherms during the southerly wind episode, with a slight sea surface temperature increase from $13.4^{\circ} \mathrm{C}$ to $13.7^{\circ} \mathrm{C}$. In contrast, there was an uplift of the isotherms during the northerly wind episodes, dropping sea surface temperature from $13.5-14^{\circ} \mathrm{C}$ to $13^{\circ} \mathrm{C}$. The bottom current time series also revealed three pulses of strong inwards velocity with values between 2.5 and $5 \mathrm{~cm} \cdot \mathrm{s}^{-1}$. The first one, which coincided with the first wind event, had a maximum value of $3 \mathrm{~cm} \cdot \mathrm{s}^{-1}$. The second one, with similar velocities, happened under relatively calm winds in April $24^{\text {th }}$. Maximum velocities (> 5 $\mathrm{cm} \cdot \mathrm{s}^{-1}$ ) were reached just at the beginning of the strong northerly wind event, around April $27^{\text {th }}$. The river contribution ranged between 50 to $70 \mathrm{~m}^{3} \cdot \mathrm{s}^{-1}$ during the first event of southerly winds and it was practically nill after that. Finally, there were two events of significant swell from northwest of about $4 \mathrm{~m}$ the first and last days.

The summer cruise (Figure 4) was characterized by northerly winds, especially intense during the first half of the period, from July $10^{\text {th }}$ to $17^{\text {th }}$. The $50 \%$ percentile of mean wind regime was around $3.4 \mathrm{~m} \cdot \mathrm{s}^{-1}$. This period was marked by high thermal 
stratification, with minimum values of $13^{\circ} \mathrm{C}$ and maxima of $20^{\circ} \mathrm{C}$. Bottom currents were highly variable (from -3 to $3 \mathrm{~cm} \cdot \mathrm{s}^{-1}$ ) during the first third of the period (July $8^{\text {th }}$ to $13^{\text {th }}$ ) associated with the highest alternation from southerly to northerly winds. Subsequently, current speed weakened concomitant with a decreasing in wind intensity. Runoff and waves were basically negligible (runoff $<10 \mathrm{~m}^{3} \cdot \mathrm{s}^{-1}$ and $\mathrm{Hs}<2 \mathrm{~m}$ ).

Two periods can be distinguished for the autumn cruise (Figure 5). The first one (October $8^{\text {th }}$ to November $5^{\text {th }}$ ) was characterized by an alternation of southerly and northerly wind episodes associated with the successive passage of storms fronts (the $50 \%$ percentile of the wind speed main regime in Silleiro Buoy was $8.0 \mathrm{~m} \cdot \mathrm{s}^{-1}$ ) and high rainfall. By contrast, there was a sustained event of northerly winds from November $5^{\text {th }}$. Temperatures showed a smaller range of variation $\left(13^{\circ} \mathrm{C}-16.3^{\circ} \mathrm{C}\right)$ than for summer but higher than spring. The time evolution of temperature was concomitant with wind and current variations. The bottom current field for this autumn sampling also presented two contrasting periods. During the first one, velocities seemed to respond to the alternate wind pattern, with successive inflows and outflows of high-speed values ranging from $10 \mathrm{~cm} \cdot \mathrm{s}^{-1}$ to $9 \mathrm{~cm} \cdot \mathrm{s}^{-1}$. In the second period, the currents were not so variable in direction and intensity. Runoff was threefold for the October month climate average (Climatological Yearbook of Galicia 2004, www.meteogalicia.es), reaching maxima of $178 \mathrm{~m}^{3} \cdot \mathrm{s}^{-1}$. In November, coinciding with the second period, there was a significant decrease in rainfall and river discharge into the Ría. It was autumn when more events of high southerly waves occurred and these coincided with downwelling conditions.

Contrary to expectations, sustained intense northerly winds prevailed during the entire winter cruise (Figure 6). The $50 \%$ percentile of the wind speed main regime in Silleiro Buoy was $7.7 \mathrm{~m} \cdot \mathrm{s}^{-1}$. Water column thermal structure was characterized by strong vertical mixing, with temperatures between $11-12^{\circ} \mathrm{C}$. Alike UI, bottom currents 
were always inwards and relatively intense compared with previous periods, with maxima of $5.5 \mathrm{~cm} \cdot \mathrm{s}^{-1}$. Rainfall was lower than the medium climate month (Climatological Yearbook of Galicia 2005, www.meteogalicia.es), causing a runoff lower than $5 \mathrm{~m}^{3} \cdot \mathrm{s}^{-1}$ most of the time. Swell was relatively high, up to $7 \mathrm{~m}$, but from the fourth quadrant (West to North).

\subsection{Temporal variability of the logarithmic profile and bottom shear stress.}

In order to describe the behavior of the ADCP bottom currents, we have applied the profile method, as previously described, to the residual, tidal and total velocity series. The time intervals between velocity profiles have been 1 hour for the residual, 10 minutes for tidal and $15 \mathrm{~s}$ for total velocity series. Those profiles with significant logarithmic fit have been selected, considering n-2 grades of freedom ( $\mathrm{n}$ is the number of velocity layers considered for the fit) and a confidence interval of 95\%. The percentage of velocity profiles with significant logarithmic adjustment has been on average $64.5 \%$ in the case of residual speeds, $75.4 \%$ for tidal speeds and $61.6 \%$ for total speeds (Table 2).

Two examples of residual velocity adjustment under upwelling conditions (April $27^{\text {th }}-28^{\text {th }}$ ) with practically no continental runoff are shown in Figure 7 . We have divided the upwelling event into two phases, spin-up (from 7:30h to $22: 30 \mathrm{~h}$ April $27^{\text {th }}$ ) and spindown (from 23:30h April $27^{\text {th }}$ to $14: 30 \mathrm{~h}$ April $28^{\text {th }}$ ) with 5 velocity profiles defining the development of each phase. As the Upwelling Index (UI) increases during the spin-up of the upwelling event (Figure $7 \mathrm{a}$ ), the shear stress and also the $\mathrm{R}^{2}$ of the logarithmic profile adjustments increase. Conversely, as the residual velocity decreases during the spin-down of the upwelling event, concomitant with UI weakening, shear stress values 
get lower and the logarithmic profiles become less defined (Figure 7b). A similar pattern is also observed for the downwelling spin-down event (distribution not shown).

In the case of tidal component, Figure 8 shows the middle tidal cycle (during a neap tide period, from 22:15 April $27^{\text {th }}$ to $3: 35$ April $28^{\text {th }}$ ) divided into the sequence from low-tide (slack waters) to medium flood phase (Figure 8a) and the sequence from medium flood phase to high tide (Figure 8b). It can be seen that when the 1mab tidal speed increases (white bar graph in Figure 8), the logarithmic profile gets developed. Simultaneously, there is an increase in shear stress (gray bars) and the $\mathrm{R}^{2}$. During the second part (Figure 8b) a similar progression is observed, i.e. as the tidal speed decreases, the logarithmic profile fades.

\subsection{Velocity and shear stress mean regimes}

Based on the velocity profiles with significant adjustment, as described in the previous section, we have compared the velocity regime and shear stress for the four studied periods. Figure 9a shows the shear stress values for residual (red dots), tidal (blue dots) and total (black dots) components during the entire study year. Comparison of the three components clearly demonstrates that tidal currents generate greater bottom shear stress values than the residual ones, while the total shear stress are the highest ones with values up to $0.7 . \mathrm{N} \cdot \mathrm{m}^{-2}$. The tidal shear stress reaches a maximum value of $0.19 \mathrm{~N} \cdot \mathrm{m}^{-2}$, while residual values do not exceed $0.14 \mathrm{~N} \cdot \mathrm{m}^{-2}$. As expected, tidal values show a temporal modulation due to the harmonic nature of the tidal currents, as happens with the tidal range (Figure 9c). The highest shear stress values were registered during the autumn cruise, doubling the average tidal values for other periods. Residual maximum values were observed during the neap tide of autumn. Autumn and spring share a similar trend in the residual component, with more significant fits and higher 
values, while the summer residual series has relatively less amount of data than the other periods indicating a relatively lower number of significant fits (Table 2). Spring only includes the neap tidal phase. In autumn neap and spring tides were captured covering the equinoctial period. The total shear stress shows the influences of the residual and tidal currents.

Comparison of the mean regimes of residual speed for the four study periods (Table 3), evidence the different behavior during the winter cruise due to its different and less steep slope (Figure 10a). In contrast, the other 3 periods have similar mean regimes with the highest values for the autumn, followed by the spring and summer cruises. In this way, winter has the highest values for medium conditions ( $\mathrm{P} 50 \%$ is $4.1 \mathrm{~cm} \cdot \mathrm{s}^{-1}$ ) compared with the other periods (P50\% of 3.3, 1.7 and $0 \mathrm{~cm} \cdot \mathrm{s}^{-1}$ for autumn, spring and summer respectively). However, the autumn cruise has the greatest average energetic conditions, with $\mathrm{P} 95 \%$ of $8.7 \mathrm{~cm} \cdot \mathrm{s}^{-1}$ versus $6.7 \mathrm{~cm} \cdot \mathrm{s}^{-1}$ for winter.

The distribution of the mean regimes for the residual shear stress is different from the speed mean regimes. The autumn period clearly resulted in higher mean regime conditions (Figure 10b), with more intense medium (P50\% of $0.011 \mathrm{~N} \cdot \mathrm{m}^{-2}$ ) and energetic $\left(\mathrm{P} 95 \%\right.$ of $\left.0.059 \mathrm{~N} \cdot \mathrm{m}^{-2}\right)$ conditions. Medium conditions for the winter cruise correspond to the second highest ones (P50\% $0.006 \mathrm{~N} \cdot \mathrm{m}^{-2}$ ) and to the third ones in energetic conditions ( $\mathrm{P} 95 \%$ of $0.019 \mathrm{~N} \cdot \mathrm{m}^{-2}$ ). The spring mean regime shows two different slopes; the first one up to $90 \%$ percentile with a lower slope than the second one, indicating two different behaviors for this cruise. Medium conditions for summer are less intense than the others $\left(\mathrm{P} 50 \%\right.$ of $\left.0 \mathrm{~N} \cdot \mathrm{m}^{-2}\right)$, but for energetic conditions achieves the same value as winter $\left(\mathrm{P} 95 \%\right.$ of $\left.0.019 \mathrm{~N} \cdot \mathrm{m}^{-2}\right)$.

Mean regimes for tidal speeds do not follow the distribution observed for residual ones (Figure 10c). Firstly, winter and autumn cruises present similar average conditions 
with P50\% of 7.0 and $6.7 \mathrm{~cm} \cdot \mathrm{s}^{-1}$ for winter and autumn respectively (Table 4). Second, the medium conditions for the summer cruise are more intense than the spring ones (tidal velocity P50\% of $4.3 \mathrm{~cm} \cdot \mathrm{s}^{-1}$ for summer and $3.4 \mathrm{~cm} \cdot \mathrm{s}^{-1}$ for spring). However, for energetic conditions, winter has more tidal velocity levels (P95\% of $\left.15.1 \mathrm{~cm} \cdot \mathrm{s}^{-1}\right)$ than autumn (P95\% of $\left.13.9 \mathrm{~cm} \cdot \mathrm{s}^{-1}\right)$ and spring more intense than summer (P95\% of 10.8 and $9.1 \mathrm{~cm} \cdot \mathrm{s}^{-1}$ for spring and summer respectively).

Mean regimes for tidal shear stress clearly discern the autumn cruise from the other three cruises (Figure 10d). Mean regime for autumn presents more intense medium and energetic conditions with $\mathrm{P} 50 \%$ of $0.038 \mathrm{~N} \cdot \mathrm{m}^{-2}$ and $\mathrm{P} 95 \%$ of $0.132 \mathrm{~N} \cdot \mathrm{m}^{-2}$. Spring and summer have similar conditions as it obtained for the mean regime of tidal currents, with $\mathrm{P} 50 \%$ of $0.012(0.013) \mathrm{N} \cdot \mathrm{m}^{-2}$ for spring (summer) and energetic ones; P95\% of $0.049(0.051) \mathrm{N} \cdot \mathrm{m}^{-2}$ for spring (summer). Finally, winter represents the lowest values with $\mathrm{P} 50 \%$ of $0.011 \mathrm{~N} \cdot \mathrm{m}^{-2}$ and $\mathrm{P} 95 \%$ of $0.039 \mathrm{~N} \cdot \mathrm{m}^{-2}$.

In the case of total currents (Table 5), the mean regime for speed and shear stress is a combination of residual and tidal components. For the four study periods, the mean regime of total currents has the highest values but the relative importance of some periods over the others changes from the order described for the tidal currents. This points that the contribution of residual currents is sufficiently important to modify the order of relative importance. Comparing with the tidal regime, in the first case of speed regime (Figure 10e), the autumn period has the highest values (P95\% $17.98 \mathrm{~cm} \cdot \mathrm{s}^{-1}$ ) relegating the winter period $\left(\mathrm{P} 95 \% 17.49 \mathrm{~cm} \cdot \mathrm{s}^{-1}\right)$. Spring continues with higher values (P50\% 5.28 and P95\% $\left.12.58 \mathrm{~cm} \cdot \mathrm{s}^{-1}\right)$ than summer (P50\% 1.44 and $\left.\mathrm{P} 95 \% 10.85 \mathrm{~cm} \cdot \mathrm{s}^{-1}\right)$.

For the total shear stress regime derived from the tidal components (Figure 10f) the relative importance of the periods only varies in the case of winter which has higher 
values $\left(\mathrm{P} 95 \% 0.149 \mathrm{~N} \cdot \mathrm{m}^{-2}\right)$ than spring $\left(\mathrm{P} 95 \% 0.148 \mathrm{~N} \cdot \mathrm{m}^{-2}\right)$ and summer $(\mathrm{P} 95 \% 0.133$ $\left.\mathrm{N} \cdot \mathrm{m}^{-2}\right)$. The autumn has the highest values (P50\% 0.098 and $\left.\mathrm{P} 95 \% 0.336 \mathrm{~N} \cdot \mathrm{m}^{-2}\right)$.

\section{Discussion}

\subsection{Analysis of the relationship between bottom velocity and oceanographic conditions}

In this work, we present for the first time, high temporal resolution of bottom currents in the middle -inner sector of the Ría de Vigo, complementing previous studies based on upwards-looking ADCP measurements (Míguez et al, 2001; Piedracoba et al., 2005). Observed bottom currents, with maximum values of $12 \mathrm{~cm} \cdot \mathrm{s}^{-1}$ at $2 \mathrm{mab}$, are consistent with current data reported in these previous studies. Míguez et al. (2001) showed maximum residual surface currents of $30 \mathrm{~cm} \cdot \mathrm{s}^{-1}$, while at subsurface layers values reached around $10 \mathrm{~cm} \cdot \mathrm{s}^{-1}$ for the north mouth and around $4 \mathrm{~cm} \cdot \mathrm{s}^{-1}$ for the south mouth of the Ría. Piedracoba et al. (2005) also registered the same order of magnitude for currents at 7 mab in a site between Punta Borneira and Cabo de Mar (Figure 1).

Our results (Figures $3-6$ ) also show that bottom currents respond to the oceanographic conditions, modulated by shelf winds, thermal stratification and runoff. According to the EOF analysis results (Table 6), about 55\% of the variability (EOF 1) is explained as follows: more positive (negative) UI values are correlated with more positive (negative) current values and both are correlated with more positive (negative) temperature differences between the bottom and surface current $\left(\Delta \mathrm{T}_{\mathrm{BS}}\right)$. The UI-current correlation relates a more positive (negative) circulation pattern in the Ría with more intense offshore (onshore) Ekman transport in the shelf. This relationship is in agreement with the well-known two-layer circulation pattern of the Ría (Upwelling 
Figure 11a and Downwelling Figure 11c).Concomitantly, more positive (negative) bottom-surface temperature differences can be explained by upwelling (downwelling) conditions. EOF 2 explains about $28 \%$ of the variability and represents a relationship between UI and the thermal gradient and no contribution of bottom current; opposite to EOF 1. This situation occurs under downwelling conditions when bottom-surface temperature difference is not so negative. On the other hand, EOF 3 shows a correlation between UI and bottom current with a minor contribution of the thermal gradient. The explained variability by EOF 3 is about $16 \%$ of the total variability and corresponds to situations where the correlation between bottom currents and UI is opposite to the expected for the two-layer circulation model of the Ría.

Although most of the variability is explained by a UI-current- $\Delta \mathrm{T}_{\mathrm{BS}}$ correlation in an expected way by the two-layer circulation model, there is also a fair amount of variability not explained by the same model. Previous studies (Fraga and Prego, 1989; Álvarez-Salgado et al., 2000 and Gilcoto et al., 2007) describe or point to the presence of an inner positive circulation cell linked to the development of a front in a location outwards from our mooring position (Figure 11b). The development of this front has been related to high runoff and downwelling conditions. To investigate a possible influence of this front in our observations, the data was segmented to consider low and average-high runoff conditions and the EOF analysis was repeated for each dataset. Here, we have considered as low runoff conditions those periods with runoff values below $18 \mathrm{~m}^{3} \cdot \mathrm{s}^{-1}$ (65\% of the original data) and average-high runoff conditions those periods with runoff values above or equal to $18 \mathrm{~m}^{3} \cdot \mathrm{s}^{-1}$. The threshold of $18 \mathrm{~m}^{3} \cdot \mathrm{s}^{-1}$ was computed from Oitavén-Verdugo climatologic runoff (Otero et al., 2010) as 1 standard deviation bellow the average runoff. 
EOF results show that under low runoff conditions, the first mode keeps the UIcurrent- $\Delta \mathrm{T}_{\mathrm{BS}}$ relationship described above, but the variability explained by this mode increases to about $68 \%$. Under average-high runoff conditions, the first mode shows the same relationship, but the explained variability is reduced to about $50 \%$. However, the relationship of previous EOF 2 is not present in either the low runoff or the averagehigh runoff case. In this re-analysis, this previous relationship among UI, currents and $\Delta \mathrm{T}_{\mathrm{BS}}$ is localized in EOF 2 under average-high runoff conditions (EOF2ahr here on) and EOF 3 under low runoff conditions (EOF31r here on). Most interestingly, EOF2ahr explains $30 \%$ of the average-high runoff data variability and shows a correlation between current and thermal gradient opposite to the one of EOF 1 and independent from the UI. This independence is not so strong in EOF3lr, although this EOF explains only $14 \%$ of the low runoff data variability. Decoupling of the current and $\Delta \mathrm{T}_{\mathrm{BS}}$ from the UI could be explained by the presence of a barrier-like structure similar to the aforementioned front. This front would, to some extent, isolate the interior of the Ría from the cross-shelf Ekman transport.

Encouraged by these results, and to further investigate the possible presence of a inner positive circulation cell affecting our data, we have divided the average-high runoff data in two datasets, one under downwelling conditions $(15 \%$ of the original data) and other under upwelling conditions (19\% of the original data). Under downwelling conditions, an EOF showing correlations similar to EOF02ahr is still present (Mode 2), while under upwelling conditions it does not appear.

From these analyses we could hypothesize that, under downwelling conditions and average-high runoff, the current is, to some degree, decoupled from the UI and related to the thermal gradient in a way that resembles the circulation schema induced by a front generated by the opposition of runoff to surface inward Ekman. 


\subsection{Variability of the bottom boundary layer dynamics}

\subsubsection{Factors controlling logarithmic profile}

Bottom currents in the Ría de Vigo respond to a logarithmic behavior most of the time, with a significant fit of $64.5 \%$ for residual cases, $75.4 \%$ for tidal cases and $61.6 \%$ for total currents (Table 2). There is a development of the logarithmic profile at maximum velocities, showed by higher $\mathrm{R}^{2}$. In fact, we have observed that shear stress increases with velocity, as it occurs during the spin up of an upwelling event. Likewise, tidal shear stress intensity is modulated with the ebb and flood cycle and also with the neap and spring tide variations. The cases in which there was not a significant fit, bottom currents were low and the configuration of velocity profile was not organized or was practically invariable in vertical.

The analysis of hourly data shows that, in simple conditions with no significant river, there is a clear relationship among shelf winds and bottom shear stress (Figure 7). The spin-up and spin-down phases of an upwelling event are concomitant with the development and destruction of the logarithmic profile. Consequently, when the alternation of wind direction is high, i.e. when there is an alternation of upwelling and downwelling pulses, as in autumn and spring, there is more frequent occurrence of high levels of shear stress. Conversely under conditions of sustained winds the logarithmic profile is not so well developed and the number of significant fits diminishes, as observed during the last part of summer period and during winter (Figure 4 and 6). However there are other factors (or factors combination) that can modulate this dynamic behavior. 
We have previously discussed how the runoff could modify the general circulation pattern inside the Ría, either enhancing the positive estuarine circulation under upwelling conditions or even provoking a double cell circulation under conditions of downwelling (Figure 11b). In this sense, runoff could increase the variability of the velocity pulses direction, favoring the development of logarithmic profile and thus the generation of higher levels of bottom shear stress, as it can be seen in the autumn period (Figure 5).

Other factor to be taking into account is the water column stratification that can exert profound effects on structure and dynamics of the BBL (Boudreau and Jorgensen, 2001). The presence of a stable stratification in the BBL reduces the vertical, turbulent transport of momentum, mass and heat and can distorts the shape of the velocity profile (Friedrichs et al. (2000)). This could have occurred during summer when there was a strong thermal stratification and the thermocline was closer to the bottom than in the other periods.

During winter water column homogeneity favors a minor gradient in the velocity (Figure 11d) affecting the logarithmic velocity profile. In contrast to the other periods, the winter velocity profile is more homogenous and its lower part is closer to the bottom, with lower total, residual and tidal shear stress even when the bottom currents were higher.

Waves play an important role in the bottom dynamics indirectly by the influence over the velocity profile (Davies et al., 1988) or directly by the generation of wave shear stress. The wave-current interaction summed up with the direct action of currents and waves determine the dynamics within the BBL (Van Rijn, 1993). In the Rías Baixas several previous studies (Rey et al. (2000; 2005), Vilas et al. (2005), and Mohamed. et al. (2011)) have analyzed the effect of waves. According to them, the surface bottom 
sediment distribution and early diagenesis in the Rías Baixas would be correlated with the wave energy pattern and with depth. This effect is more evident in the most exposed zones of the Ría, near the Ría mouths and in the lateral margins of the outer and middle section of the Ría. However, the analysis carried out in this work shows how currents in the inner Ría can be determinant generating levels of total shear stress that exceed the limit for the resuspension. This occurs mainly during autumn concomitant with downwelling situations when it is more probable the existence of southerly swells that can reach the inner Ría. This coupling among southerly winds, strong currents and southerly swells leads to the most energetic situations in the Ría, as previously described by Vitorino et al (2002) on the northern portuguese shelf.

\subsubsection{Shear stress and resuspension}

In our study region, bottom shear stress ranged between 0 and $0.059 \mathrm{~N} \cdot \mathrm{m}^{-2}$ for the residual, between 0.011 and $0.132 \mathrm{~N} \cdot \mathrm{m}^{-2}$ for the tidal and between 0 and $0.336 \mathrm{~N} \cdot \mathrm{m}^{-2}$ for the total component (under medium and energetic conditions respectively in the three cases). Although in general the magnitude of tidal shear stress is greater than the residual shear stress, the residual value exceeds the tidal ones under neap tide conditions, even doubled or tripled the tidal component.

Shear velocities $\left(U_{*}\right)$ were around $0-0.33 \mathrm{~cm} \mathrm{~s}^{-1}$ (residual), $0.33-0.61 \mathrm{~cm} \cdot \mathrm{s}^{-1}$ (tidal) and $0-0.98 \mathrm{~cm} \cdot \mathrm{s}^{-1}$ (total) for medium conditions in the Ría de Vigo. These values were similar to those ones reported by Friedrichs et al. (2000) for Ekckrnförder Bay, with a medium shear velocity value around $0.51 \mathrm{~cm} \cdot \mathrm{s}^{-1}$. Under energetic situations in the Ría de Vigo, these values reached $0.76 \mathrm{~cm} \cdot \mathrm{s}^{-1}$ for residuals, $1.13 \mathrm{~cm} \cdot \mathrm{s}^{-1}$ for tidal and 1.81 $\mathrm{cm} \cdot \mathrm{s}^{-1 \text { for }}$ total currents. This maximum total shear velocity is of the same order as values 
observed by these authors on the Northern California Shelf $\left(1.7-1.9 \mathrm{~cm} \cdot \mathrm{s}^{-1}\right)$ and lower than the maximum observed in Chesapeake Bay $\left(1.3-3.9 \mathrm{~cm} \cdot \mathrm{s}^{-1}\right)$.

Alejo et al. (1998) investigated the critical conditions for generating erosion on cohesive sediments like the sediments of the main channel of the Ría de Vigo (Vilas et al., 2005) based on flume experiments. These authors found that the first stage of sediment erosion requires energetic conditions equivalent to a shear stress of $0.33 \mathrm{~N} \cdot \mathrm{m}^{-2}$ (critical shear velocity $\left(\mathrm{u}_{\mathrm{cr}}\right.$ ) $1.8 \mathrm{~cm} \cdot \mathrm{s}^{-1}$ ). This means that during autumn period the shear stress was strong enough $(5.12 \%$ of the time $)$ to re-suspend fine cohesive sediments from the main channel of the Ría de Vigo. However, if we consider near seabed aggregates and phytodetritus material, as observed in the benthic boundary layer at different continental margins (Sternberg et al., 1986; Townsend et al., 1992; Thomsen, 2002) and observed trough submarine videos in the Ría de Vigo, their $\mathrm{u}^{*}{ }_{\mathrm{cr}}$ ranged from 0.4 to $0.9 \mathrm{~cm} \cdot \mathrm{s}^{-1}$ (i.e. 0.02 to $0.08 \mathrm{~N} \cdot \mathrm{m}^{-2}$ ) for aggregates and 0.9 to $1.2 \mathrm{~cm} \cdot \mathrm{s}^{-1}$ (i.e. 0.08 to $0.15 \mathrm{~N} \cdot \mathrm{m}^{-2}$ ) for phytodetritus (Thomsen and Van Weering, 1998), implying that they are resuspended under lower flow velocity than Ría de Vigo cohesive sediments. Thus, taking into account these ranges of critical shear velocity and considering the shear stress regimes analyzed in our study, we can assess the percentage of time in which is expected to reach resuspension conditions for this material (Table 7). It is during the autumn season when these conditions are more recurrent (70\% for aggregates) and in addition it is during this season when other sources of energy take place (equinoctials tides and southerly waves), magnifying the resuspension processes. In this way, our study of BBL dynamics comes out to support previous studies suggesting that recurrent high concentrations of ammonium, phosphate and $\mathrm{CO}_{2}$ (Álvarez- Salgado et al., 1996; Rosón et al., 1999 and Nieto-Cid et al., 2005) in the water column during the autumn 
season were associated to the occurrence of resuspension processes, with no direct evidence of bottom shear velocities.

\section{Conclusions}

In this work we have analyzed bottom currents in the Ría de Vigo along with shelf winds, water column temperature and run off for four sampling periods covering the four annual seasons. Residual currents at the BBL agree with the general residual circulation pattern in the rest of the water column, established by previous works in the Ría de Vigo.

Residual, tidal and total currents at the BBL respond to a logarithmic profile fit over $61.6 \%$ of the time, with a high temporal variability during the study year. Intense thermal stratification during the summer period or strong water column mixing during the winter period reduces the contribution of currents to seabed dynamics. The most important generation of bottom shear stress is produced when there is a combination of alternation of upwelling - downwelling conditions, high rainfall and runoff, southerly swells and spring tides. These highly energetic periods mainly occur during the autumn period. In this sense, our results evidence resuspension processes during this season and support previous biogeochemistry studies pointing to sediment resuspension as the key mechanism for the high nutrient levels in the overlying water.

\section{Acknowledgements}

The authors wish to thank the captain, crew, and technicians of R/V Mytilus as well as the Group of Oceanography of the Instituto de Investigacións Mariñas (CSIC) and the Group of Physical Oceanography of the University de Vigo for their collaboration 
during the sampling program. Special thanks are owed to M. Gilcoto for their comments and suggestions. We are also grateful to Puertos del Estado for the meteorological and oceanographic data of the Silleiro buoy. N. V-R. has been funded by Isabel Barreto program of the Xunta de Galicia. Financial support for this work came from the Spanish Ministerio de Educación y Ciencia, grant REN2003-04458/MAR. This is a contribution of the Unidad Asociada CSIC-GOFUVI. We thank to the editor and reviewer for their valuables comments and suggestions.

\section{REFERENCES}

Alejo, I., Pazos, O., Bernabeu, A., Vilas, F., 1998. Erosión de fangos. Aplicación de ensayos de laboratorio al caso de la Ría de Vigo. XIII Bienal de la Real Sociedad Española de Historia Natural, P.33. Vigo.

Alonso-Pérez, F., Ysebaert, T., Castro, C.G., 2010. Effects of suspended mussel culture on benthic-pelagic coupling in a coastal upwelling system (Ría de Vigo, NW Iberian Peninsula). J. Exp. Mar. Biol. Ecol., 382(2), 96-107. doi:10.1016/j.jembe.2009.11.008.

Álvarez-Salgado, X. A., Rosón G., Pérez F.F., Figueiras F.G., Pazos Y., 1996. Nitrogen cycling in an estuarine upwelling system, the Ría de Arousa (NW Spain). I. Short-time-scale patterns of hydrodynamic and biogeochemical circulation. Mar. Ecol. Prog. Ser., 135(1-3), 259. doi:10.3354/meps 135259 .

Álvarez-Salgado, X. A., Gago, J., Miguez, B. M., Gilcoto, M., Pérez, F. F., 2000. Surface waters of the NW Iberian Margin: Upwelling on the Shelf versus Outwelling of Upwelled Waters from the Rías Baixas. Estuar. Coast. Shelf Sci., 51, 821. doi:10.1006/ecss.2000.0714. 
Arbones, B., Castro, C. G., Alonso-Pérez, F., Figueiras, F. G., 2008. Phytoplankton size structure and water column metabolic balance in a coastal upwelling system: the Ria de Vigo, NW Iberia. Aquat. Microb. Ecol., 50(2), 169. doi:10.3354/ame01160.

Blanton, J. O., Atkinson, L. P., Fernández de Castillejo, F., Lavín, A., 1984. Coastal upwelling off the Rías Bajas, Galicia, Northwest Spain. I. Hydrographic studies. Reunión Cons.Int.Explor.Mer.(183), 79.

Boudreau, B.P., Jorgensen, B.B., 2001. The Benthic Boundary Layer: Transport Processes and Biogeochemistry. Oxford University Press. ISBN 0-19-511881-2. 440 pages.

Climatological Yearbook of Galicia 2004/Anuario Climatolóxico de Galicia 2004. Consellería de Medio Ambiente e Desenvolvemento Sostible.(2005).Santiago de Compostela. ISBN 84453-3962-1.

Climatological Yearbook of Galicia 2005/Anuario Climatolóxico de Galicia 2005. Consellería de Medio Ambiente e Desenvolvemento Sostible.(2006).Santiago de Compostela. ISBN 84453-4292-4.

Davies, A.G, Soulsby, R.L., King, H.L.,1988. A numerical model of the combined wave and current bottom boundary layer. Journal of Geophysical Research, 93 (1988), pp. 491-508.

Diz, P., Frances, G., Costas, S., Souto, C., Alejo, I., 2004. Distribution of benthic foraminifera in coarse sediments, Ria de Vigo, NW Iberian margin. Journal of foraminiferal research, 34(4), 258-275. doi:10.2113/34.4.258.

Fraga, F., Prego, R., 1989. Condiciones hidrográficas previas a la purga de mar. Cuadernos da Área de Ciencias Mariñas, Seminario de Estudos Galegos, 4, 21. 
Friedrichs, C. T., Wright, L. D., Hepworth, D. A., Kim, S. C., 2000. Bottom-boundary-layer processes associated with fine sediment accumulation in coastal seas and bays. Cont. Shelf Res., 20(7), 807-841. doi:10.1016/S0278-4343(00)00003-0.

Garvine, R. W., 1985. A simple model of estuarine subtidal fluctuations forced by local and remote wind stress. Journal of Geophysical Research, 90(6 C), 11945-11948. doi:10.1029/JC090iC06p11945.

Garvine, R. W., McCarthy, R. K., Wong, K.C., 1992. The axial salinity distribution in the delaware estuary and its weak response to river discharge. Estuar. Coast. Shelf Sci., 35(2), $157-$ 165. doi:10.1016/S0272-7714(05)80110-6.

Gilcoto, M., Álvarez Salgado, X. A., Pérez, F. F., 2001. Computing optimum estuarine residual fluxes with a multiparameter inverse method (OERFIM): Application to the Ria de Vigo (NW Spain). Journal of Geophysical Research C: Oceans, 106(C12), 31303.

Gilcoto, M., Pardo, P. C., Álvarez-Salgado, X. A., Pérez, F. F., 2007. Exchange fluxes between the Ría de Vigo and the shelf: a bidireccional flow forced by remote wind. Journal of Geophysical Research C: Oceans, 112, C06001. doi:10.1029/2005JC003140.

Godin, G., 1972. The Analysis of Tides. Liverpool Univ. Press, Liverpool. UKISBN 0-85323441-8. 264pages.

Hidy, G. M., 1972. A view of recent air-sea interaction research. Bull. Am. Meteorol. Soc., 53, 1083-1102.

Jickells, T.D. 1998. Nutrient biogeochemistry of the coastal zone. Science, 281: $217-222$.

Joint, I. and Wassmann, P., 2001. Lagrangian studies of the Iberian upwelling system an introduction. A study of temporal evolution of surface production and fate of organic matter 
during upwelling on and off the NW Spanish continental margin. Progress in Oceanografphy 51(2): 217-220.

Kundu, P. K., Cohen, Ira M., 2002. Fluid Mechanics. Academic Press, cop. 2002. San Diego. ISBN 0-12-178251-4. 730 pages.

McClain, C. R., Chao, S., Atkinson, L. P., Blanton, J. O., Castillejo, F., 1986. Wind-driven upwelling in the vicinity of Cape Finisterre, Spain. Journal of Geophysical Research, 91(C7), 8470-8486.

Míguez, B. M., Farína-Busto, L., Figueiras, F. G., Pérez, F. F., 2001. Succession of phytoplankton assemblages in relation to estuarine hydrodynamics in the Ría de Vigo: A box model approach. Sci. Mar., 65(Supplement), 65-76.

Mohamed, K. J., Rey, D., Rubio, B., Dekkers, M. J., Roberts, A. P., Vilas, F., 2011. Onshoreoffshore gradient in reductive early diagenesis in coastal marine sediments of the Ria de Vigo, Northwest Iberian Peninsula. Cont. Shelf Res., 31(5), 433-447. doi:10.1016/j.csr.2010.06.006.

Montero, P., Gómez-Gesteira, M., Taboada, J. J., Ruiz-Villarreal, M., Santos, A. P., Neves, R. R., Prego, R., Pérez-Villar, V., 1999. Sobre la circulación de la ría de Vigo usando un modelo baroclínico 3-D. Boletín del Instituto Español de Oceanografía, 15(1), 31.

Nieto-Cid, M., Álvarez-Salgado, X. A., Gago, J., Pérez, F. F., 2005. DOM fluorescence, a tracer for biogeochemical processes in a coastal upwelling system (NW Iberian Peninsula). Mar. Ecol. Prog. Ser., 297, 33. doi:10.3354/meps297033.

Otero, P., Ruiz-Villareal, M., Peliz, A., Cabanas, J., 2010. Climatology and reconstruction of runoff time series in northwest Iberia: influence in the shelf buoyancy budget off Ría de Vigo. Sci. Mar., 74(2), 247-266. doi:10.3989/scimar.2010.74n2247. 
Pawlowicz, R., Beardsley, B., Lentz, S., 2002. Classical tidal harmonic analysis including error estimates in MATLAB using T-TIDE. Comput. Geosci., 28(8), 929-937, doi:10.1016/S00983004(02)00013-4.

Piedracoba, S., Álvarez-Salgado, X. A., Rosón, G., Herrera, J. L., 2005. Short-timescale thermohaline variability and residual circulation in the central segment of the coastal upwelling system of the Ria de Vigo (northwest Spain) during four contrasting periods. Journal of Geophysical Research, 110(C3). doi:10.1029/2004JC002556.

Prego, R., Fraga, F., Ríos, A. F., 1990. Water interchange between the Ria of Vigo and the coastal shelf. Sci. Mar., 54(1), 95- 100.

Prego, R., Fraga, F., 1992. A simple model to calculate the residual flows in a Spanish Ría. Hydrographic consequences in the Ria of Vigo. Estuarine Coastal Shelf Sci., 34, 603-615.

Prego, R., 1995. The biochemical cycling of dissolved silicate in a Galician Ria, Ophelia, 42, 301. doi:10.1080/00785326.1995.10431510.

Preisendorfer, W., Mobley, C. D. 1988. Principal component analysis in meteorology and oceanography. Principal component analysis in meteorology and oceanography.

Quelle, C., Besada, V., Andrade, J. M., Gutiérrez, N., Schultze, F., Gago, J., González, J. J., 2011. Chemometric tools to evaluate the spatial distribution of trace metals in surface sediments of two Spanish rías. Talanta, 87(1), 197-209, doi:10.1016/j.talanta.2011.09.062.

Rey, D., López-Rodríguez, N., Rubio, B., Vilas, F., Mohamed, K.J., Pazos, O., Bógalo, M. F. 2000. Magnetic properties of estuarine-like sediments. The study case of the Galician Rias. Journal of iberian geology, 26, 151-170. 
Rey, D., Mohamed, K.J., Bernabeu, A., Rubio, B.,Vilas, F., 2005. Early diagenesis of magnetic minerals in marine transitional environments: Geochemical signatures of hydrodynamic forcing. Mar. Geol., 215(3-4), 215-236. doi:10.1016/j.margeo.2004.12.001.

Ríos, A. F., Nombela, M. A., Pérez, F. F., Rosón, G., Fraga, F., 1992. Calculation of runoff to an estuary. Ría de Vigo. Scientia marina, 56(1), 29.

Rosón, G., Álvarez-Salgado, X. A., Pérez, F. F., 1997. A non-stationary box model to determine residual fluxes in a partially mixed estuary, based on both thermohaline properties: Application to the Ria de Arousa (NW Spain). Estuar. Coast. Shelf Sci., 44(3), 249-262. doi:10.1006/ecss.1996.0127.

Rosón, G., Álvarez-Salgado, X. A., Pérez, F. F., 1999. Carbon cycling in a large coastal embayment, affected by wind-driven upwelling: Short-time-scale variability and spatial differences. Mar. Ecol. Prog. Ser., 176, 215-230.

Rubio, B., Nombela, M.A., Vilas, F., 2000. Geochemistry of major and trace elements in sediments of the Ria de Vigo (NW Spain): An assessment of metal pollution. Mar. Pollut. Bull., 40(11), 968-980. doi:10.1016/S0025-326X(00)00039-4.

Souto, C., Gilcoto, M., Farina-Busto, L., Pérez, F. F., 2003. Modeling the residual circulation of a coastal embayment affected by wind-driven upwelling: Circulation of the Ría de Vigo (NW Spain). J. Geophys. Res. C Oceans, 108(11), 4-1.

Sternberg, R.W., Johnson, R.V., Cacchione, D.A., Drake, D.E., 1986. An instrument system for monitoring and sampling suspended sediment in the benthic boundary layer. Mar. Geol. 71, $187-199$.

Taboada, J. J., Prego, R., Ruiz-Villarreal, M., Gómez-Gesteira, M., Montero, P., Santos, A. P., Pérez-Villar, V., 1998. Evaluation of the Seasonal Variations in the Residual Circulation in the 
Ría of Vigo (NW Spain) by Means of a 3D Baroclinic Model. Estuar. Coast. Shelf Sci., 47(5), 661-670. doi:10.1006/ecss.1998.0385.

Thomsen, L., Van Weering, Tj.C.E., 1998. Spatial and temporal variability of particulate matter in the benthic boundary layer at the N.W. European Continental shelf Margin (Goban Spur). Progress in Oceanography 42(1-4): $61-76$.

Thomsen, L., 2002. The benthic boundary layer. In Berger, Wefer, (eds). Ocean Margin Systems, Springer, pp $143-155$.

Torres-López, S., Varela, R. A., Delhez, E., 2001. Residual circulation and thermohaline distribution of the Ría de Vigo: A 3-D hydrodynamical model. Sci. Mar., 65(Supplement), 277289.

Townsend, D.W., Mayer, L.M., Dotch, D., Spinrad, R.W., 1992. Vertical structure and biological activity in the bottom nepheloid layer of the Gulf of Maine. Continental Shelf Res. $12,367-387$

Van Rijn, L.C., 1993. Principles of sediment transport in rivers, estuaries and coastal seas. Aqua Publications, Amsterdam, The Netherlands. ISBN 90-800356-2-9. 654 pages.

Vilas, F., Bernabeu, A. M., Méndez, G., 2005. Sediment distribution pattern in the Rias Baixas (NW Spain): Main facies and hydrodynamic dependence. J. Mar. Syst., 54(1-4 SPEC. ISS.), 261-276. doi:10.1016/j.jmarsys.2004.07.016.

Vitorino, J., Oliveira, A., Jouanneau, J.M., Drago, T., 2002. Winter dynamics on the northern Portuguese shelf. Part 1: physical processes. Progress in Oceanography 52 (2002) 129-153.

Wooster, W. S., Bakun, A., McLain, D. R., 1976. Seasonal upwelling cycle along the eastern boundary of the North Atlantic. J. Mar. Res., 34(2), 131-141. 
Zúñiga, D., Alonso-Pérez, F., Castro, C. G., Arbones, B., Figueiras, F. G., 2011. Seasonal contribution of living phytoplankton carbon to vertical fluxes in a coastal upwelling system (Ría de Vigo, NW Spain). Cont. Shelf Res., 31(5), 414-424. doi:10.1016/j.csr.2010.09.011.

\section{Figure Legends}

Figure 1. Study area. Bathymetry of the Ría de Vigo and adjacent shelf showing the FLUVBE station, where mooring was deployed, the land based meteorological stations of Bouzas and Peinador, the shelf meteorological station located at the Seawatch buoy of Puertos del Estado off Cape Silleiro.

Figure 2. Scheme of the FLUVBE mooring deployment with a thermistor chain between sea surface and bottom (20m) and an ADCP RDI $1200 \mathrm{KHz}$ looking downwards at 3 meters above the bottom.

Figure 3. Oceanographic and meteorological conditions during the spring sampling cruise (April $21^{\text {th }} 2004$ - May $\left.6^{\text {th }} 2004\right)$. (a) Low pass filtered shelf winds $\left(\mathrm{m} \cdot \mathrm{s}^{-1}\right.$ ) measured at Silleiro Buoy. Southerly winds are positive and northerly winds negative. (b) Temperature $\left({ }^{\circ} \mathrm{C}\right)$ contour at the FLUVBE station. Dots are medium grades and solid lines entire grades. (c) Contour of the residual component of the ADCP current velocity $\left(\mathrm{cm} \cdot \mathrm{s}^{-1}\right)$ parallel to the main axis of the Ría between $0.25 \mathrm{~m}$ and $2 \mathrm{~m}$ above the bottom. Negatives are outflow velocities and positives values are inflow velocities respect to the Ría. (d) Daily average runoff $\left(\mathrm{m}^{3} \cdot \mathrm{s}^{-1}\right)$ into the Ría de Vigo and significant wave height (Hs in m) in Silleiro, Waves from the southwest (third quadrant S-W) have 
been highlighted in red. (e) Bottom shear stress $\left(\mathrm{N} \cdot \mathrm{m}^{-2}\right)$ of currents (blue line) and Upwelling Index $\left(10^{3} \mathrm{~m}^{3} \cdot \mathrm{s}^{-1} \cdot \mathrm{km}^{-1}\right)$ (red line).

Figure 4. Oceanographic and meteorological conditions during the summer sampling cruise (July $8^{\text {th }} 2004-$ July $\left.30^{\text {th }} 2004\right)$.

Figure 5. Oceanographic and meteorological conditions during the autumn sampling cruise (October $8^{\text {th }} 2004$ to November $\left.14^{\text {th }} 2004\right)$.

Figure 6. Oceanographic and meteorological conditions during the winter sampling cruise (January $18^{\text {th }} 2005-$ February $22^{\text {th }} 2005$ ).

Figure 7. Profile fit of the residual velocity. (a) Upwelling spin-up development event of April $27^{\text {th }} 2004$ with four consecutive velocity profiles 5 hours apart. Two sets of bar graphs are shown at the top of each profile. The upper one (gray) corresponds to Upwelling Index $\left(10^{3} \mathrm{~m}^{3} \cdot \mathrm{s}^{-1} \cdot \mathrm{km}^{-1}\right)$. The lower set (black) represents the value of shear stress $\left(\mathrm{N} \cdot \mathrm{m}^{-2}\right)$ obtained from the fit to 14 levels of each profile. Finally, $\mathrm{R}^{2}$ for each fit is also shown (b) Represents the same set of the spin-down of the same upwelling event.

Figure 8. Profile fit of the tidal current beginning at 22:15 April $27^{\text {th }}$ (a) from low tide to medium flood phase and (b) from medium flood phase to high tide. In each plot five profiles of tidal speed 1 hour apart are shown; profile at 2:40 April $28^{\text {th }}$ (profile 0h) is shown in both plots. The upper gray bar correspond to the tidal speed $1 \mathrm{mab}\left(\mathrm{cm} \cdot \mathrm{s}^{-1}\right)$ while the lower black bar is the shear stress $\left(\mathrm{N} \cdot \mathrm{m}^{-2}\right)$ obtained with the fit to 12 points of the tidal velocity profile. Finally, $\mathrm{R}^{2}$ for each fit is also shown 
Figure 9. (a) Time series of bottom shear stress $\left(\mathrm{N} \cdot \mathrm{m}^{-2}\right)$ for the four sampling cruises at FLUVBE station. Red, blue and black dots represent residual, tidal and total shear stress respectively. (b) Upwelling Index time series $\left(10^{3} \mathrm{~m}^{3} \cdot \mathrm{s}^{-1 \cdot} \mathrm{km}^{-1}\right)$ calculated from Silleiro buoy winds. (c) Tidal astronomical amplitude (m) in Vigo's Harbour, in the Ría de Vigo.

Figure 10. Mean regime of speed in $1 \mathrm{mab}\left(\mathrm{cm} \cdot \mathrm{s}^{-1}\right)$ and bottom shear stress $\left(\mathrm{N} \cdot \mathrm{m}^{-2}\right)$ for residual (left), tidal (midle) and total (right) currents. Colors indicate spring (green), summer (orange), autumn (magenta) and winter (blue) periods.

Figure 11. (a) Upwelling pattern in the Ría de Vigo. Northerly-Shelf winds (in red generate an Ekman transport oceanwards favoring a positive circulation into the Ría with an inflow of subsurface cold water through the bottom.

Figure 11. (b). Downwelling pattern during high runoff events. Southerly shelf winds (in red) generate surface inwards Ekman transport into the Ría (arrows in red and white) causing a negative circulation. At the same time, there is a significant runoff in the inner part of the Ría (arrows in blue). Both flows favor a double cell system into the Ría generating a convergence front where surface currents sink. Typical swell comes from the Southwest.

Figure 11. (c) Downwelling pattern in the Ría de Vigo with no runoff. Southerly shelf winds (in red) generate a surface inwards Ekman transport into the Ría (arrows in red 
and white) which creates a negative circulation with outflow through the bottom. Typical swell comes from the Southwest.

Figure 11. (d). Upwelling pattern in the Ría de Vigo during events of intense water column mixing. Northerly shelf winds (in red) generate a surface outwards Ekman transport from the Ría (blue and white arrows) favoring a positive circulation with inflow through the bottom. Typical swell comes from Northwest. 


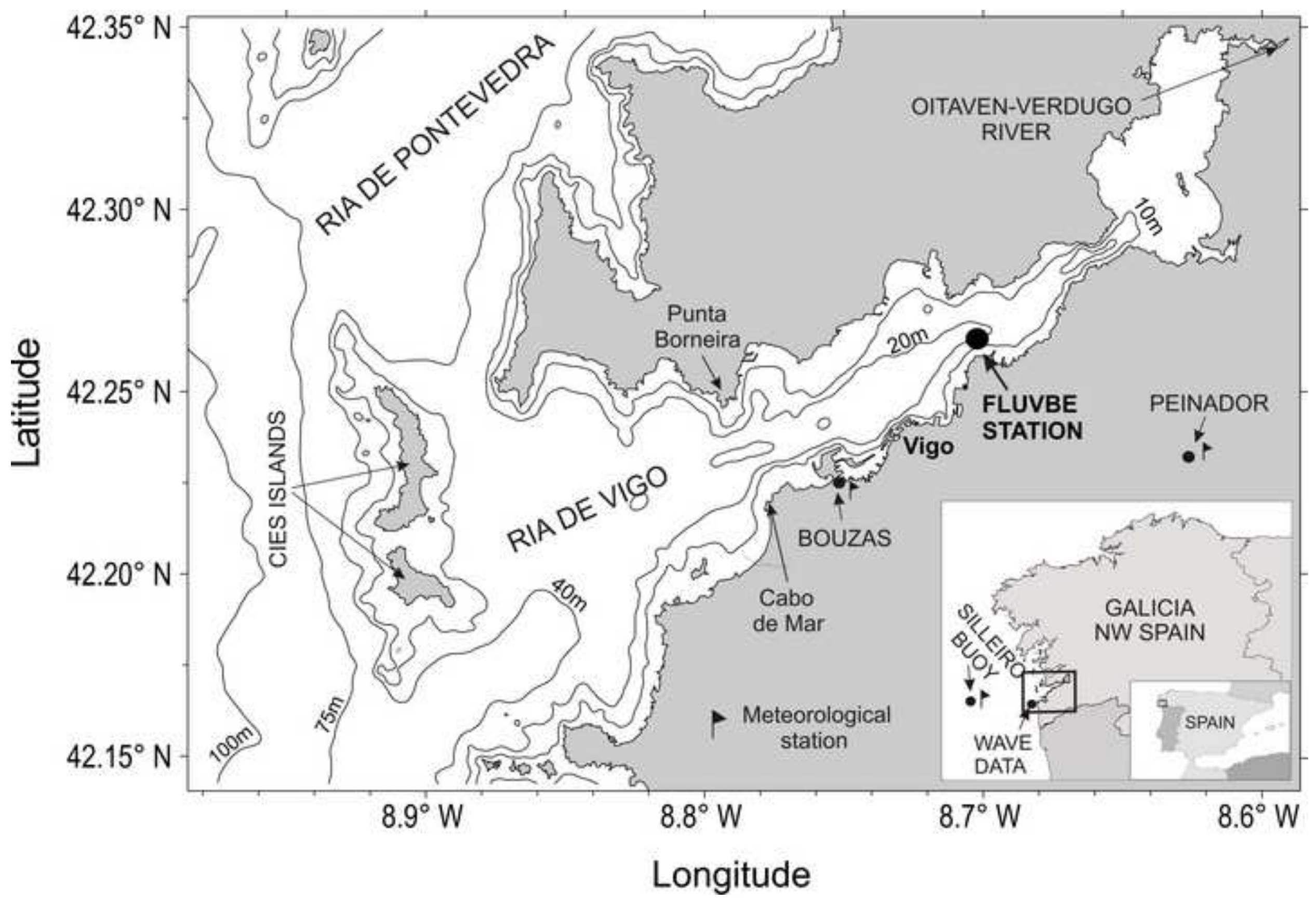


Click here to download high resolution image

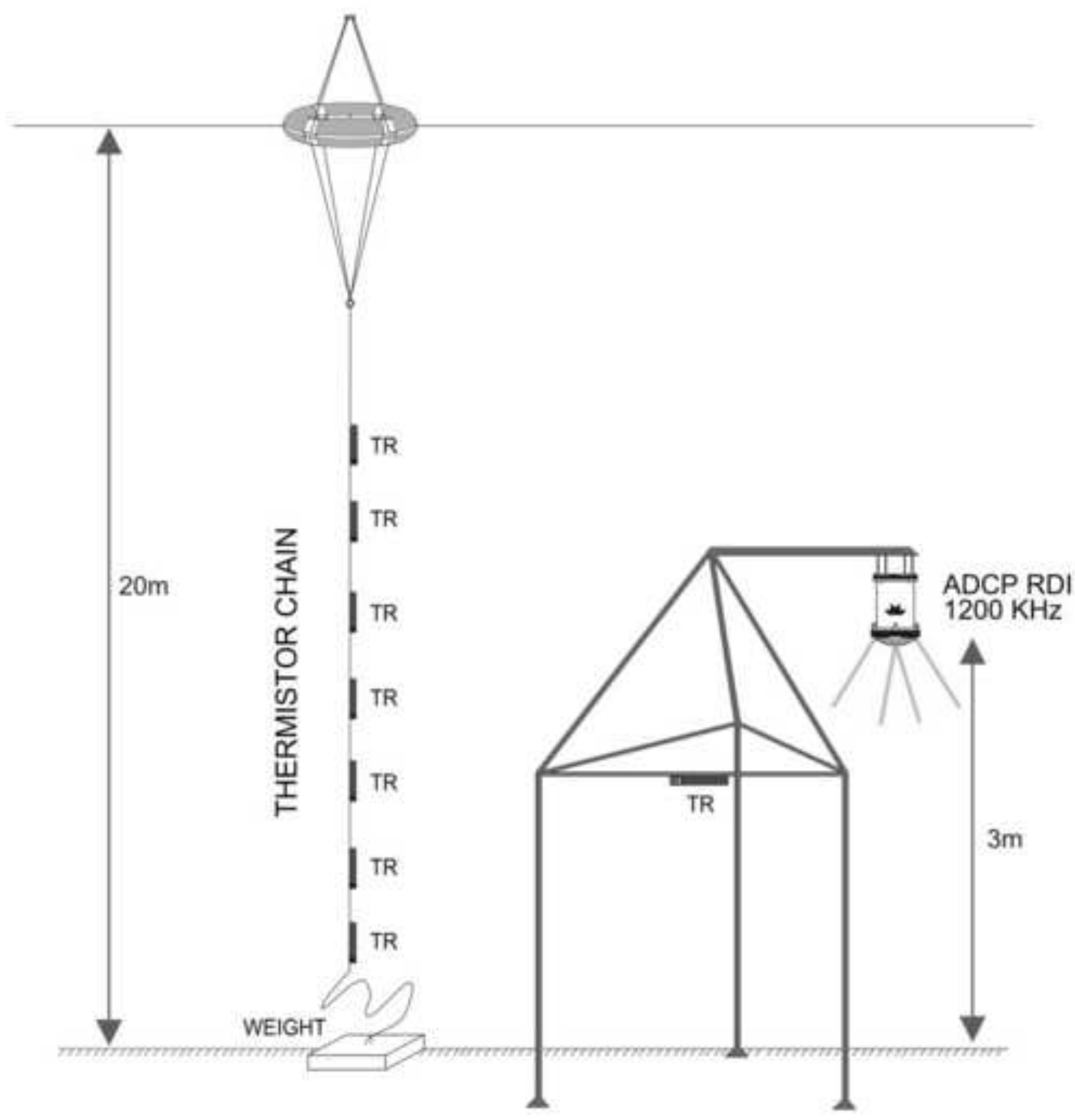


Click here to download high resolution image
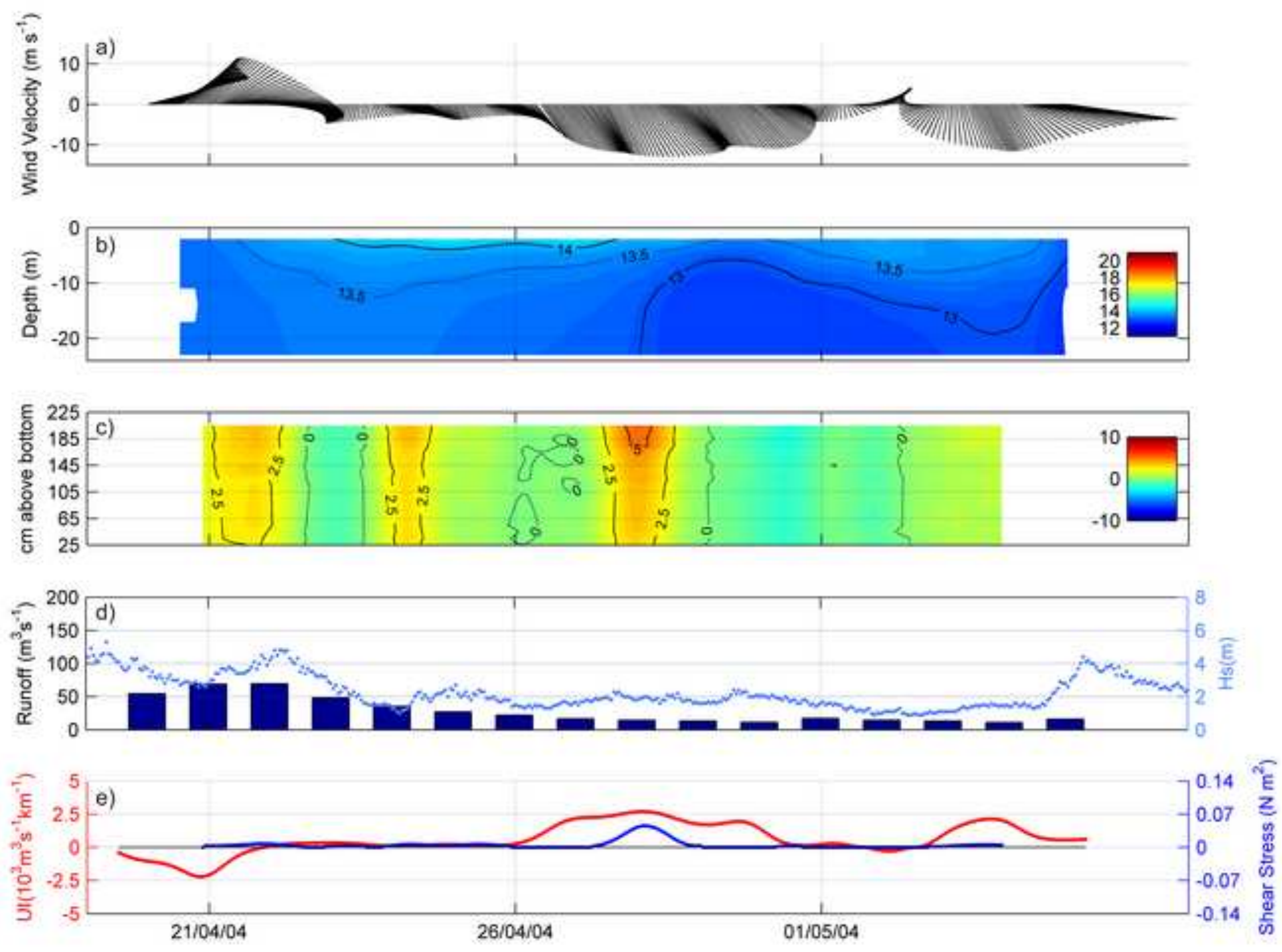
Click here to download high resolution image
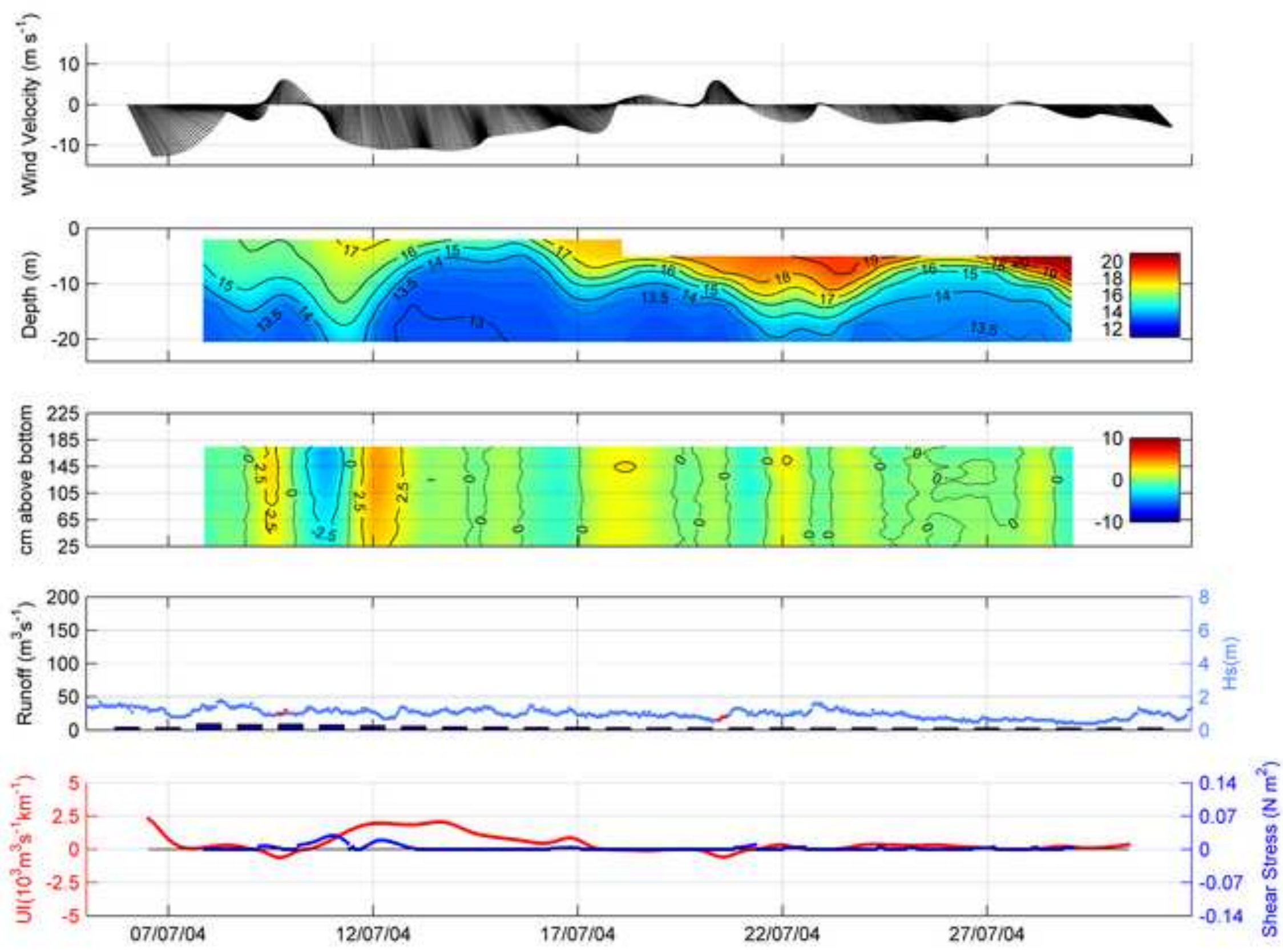
Click here to download high resolution image
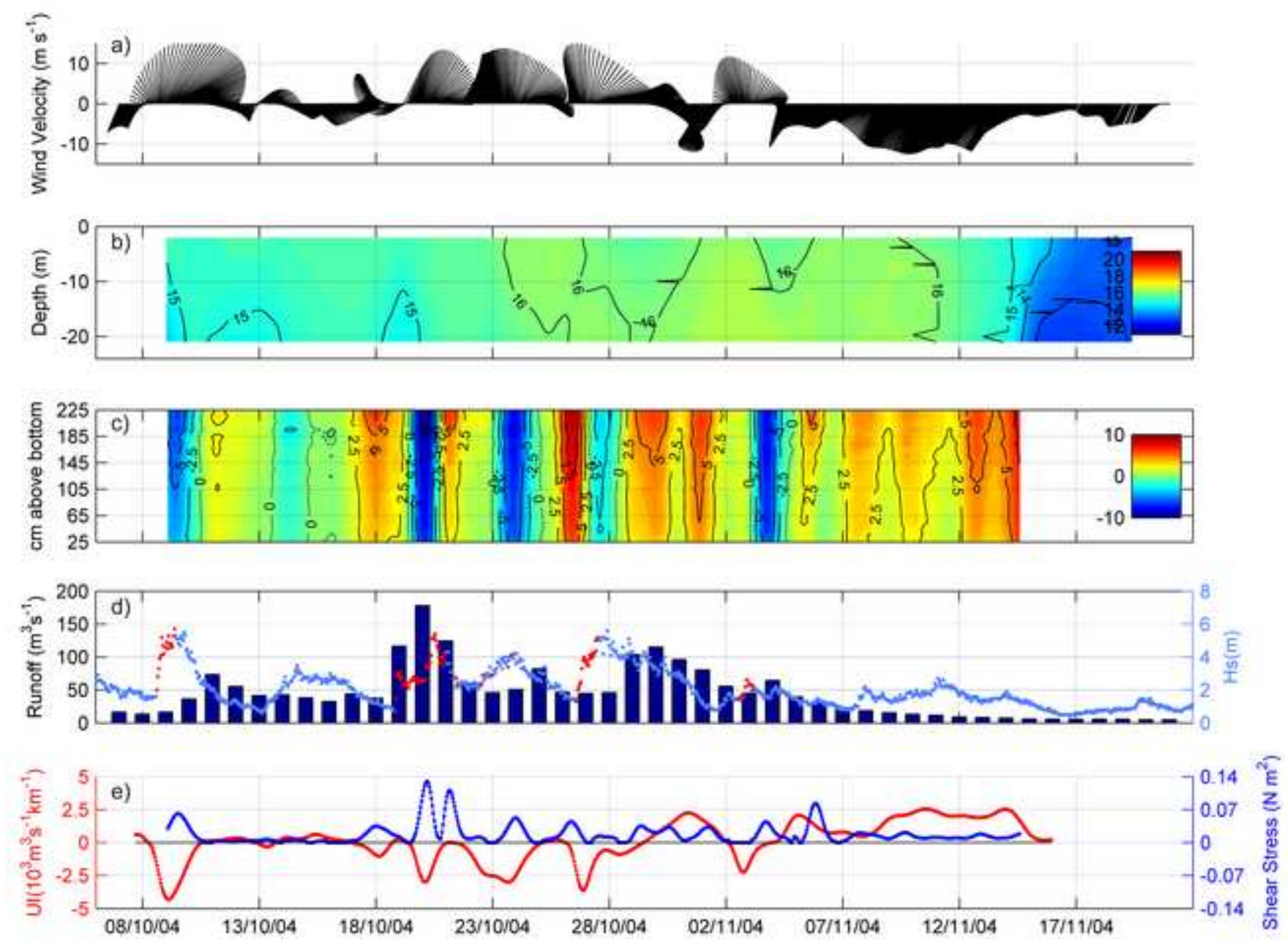

E


Click here to download high resolution image
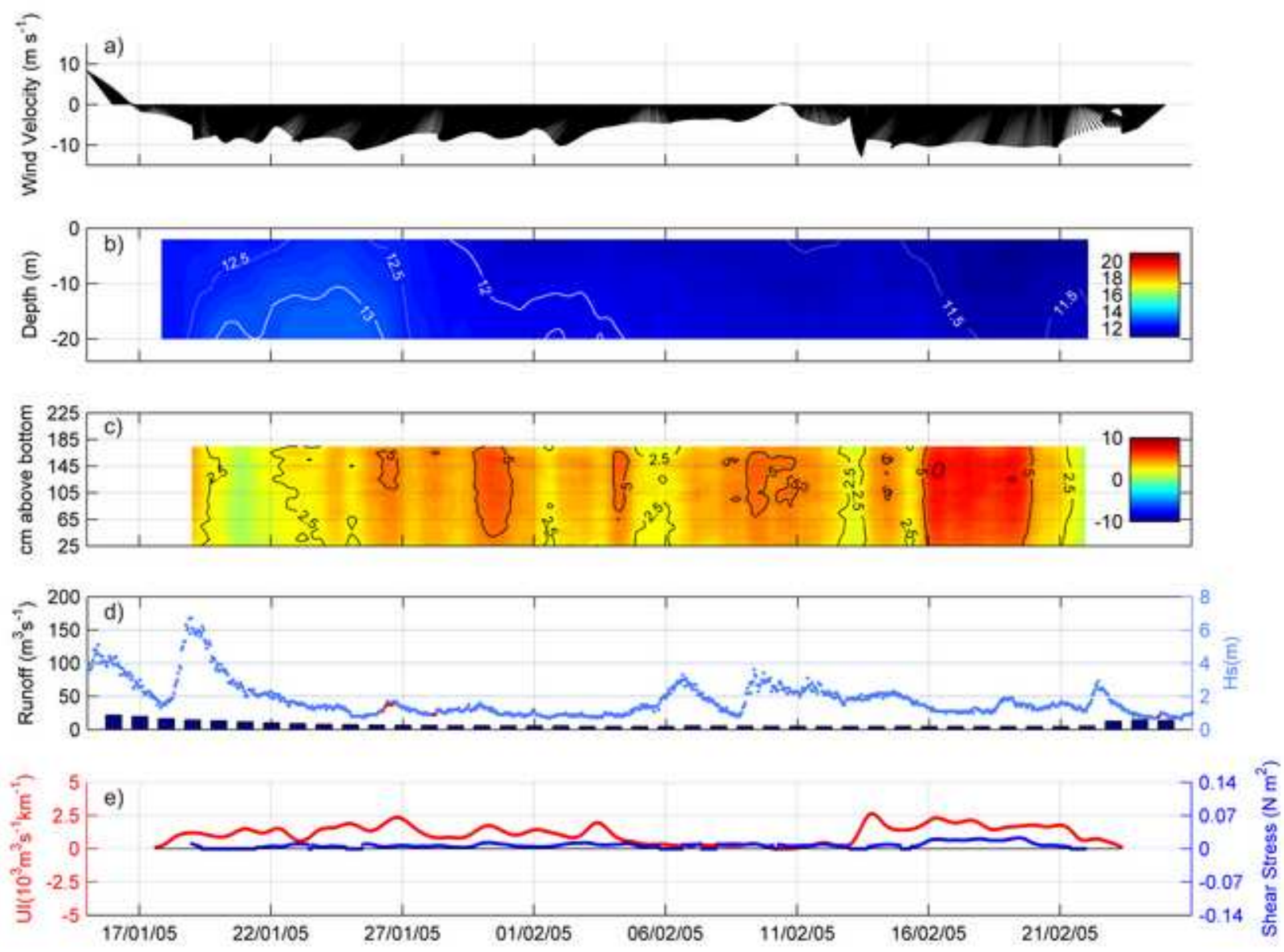

E



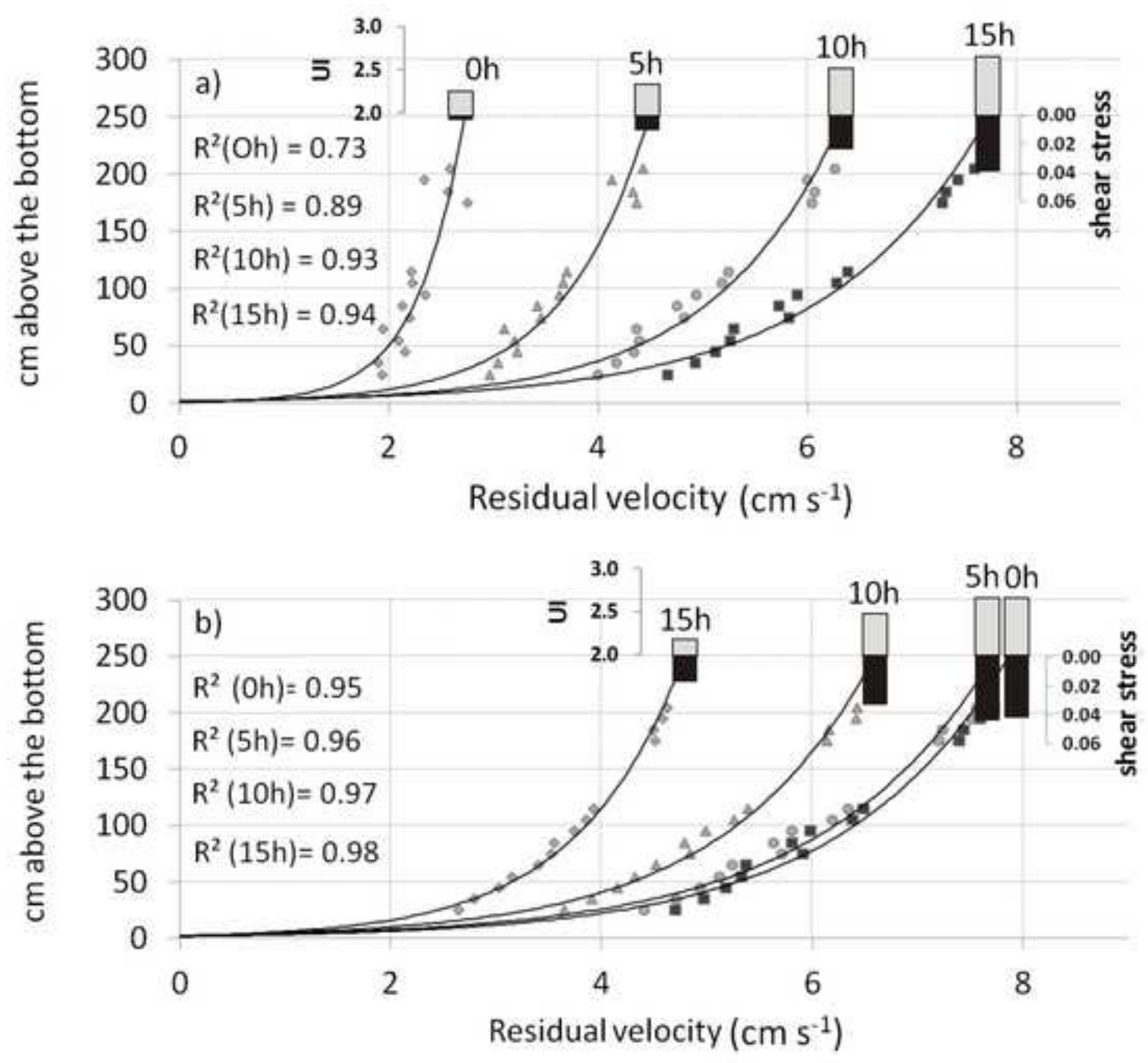

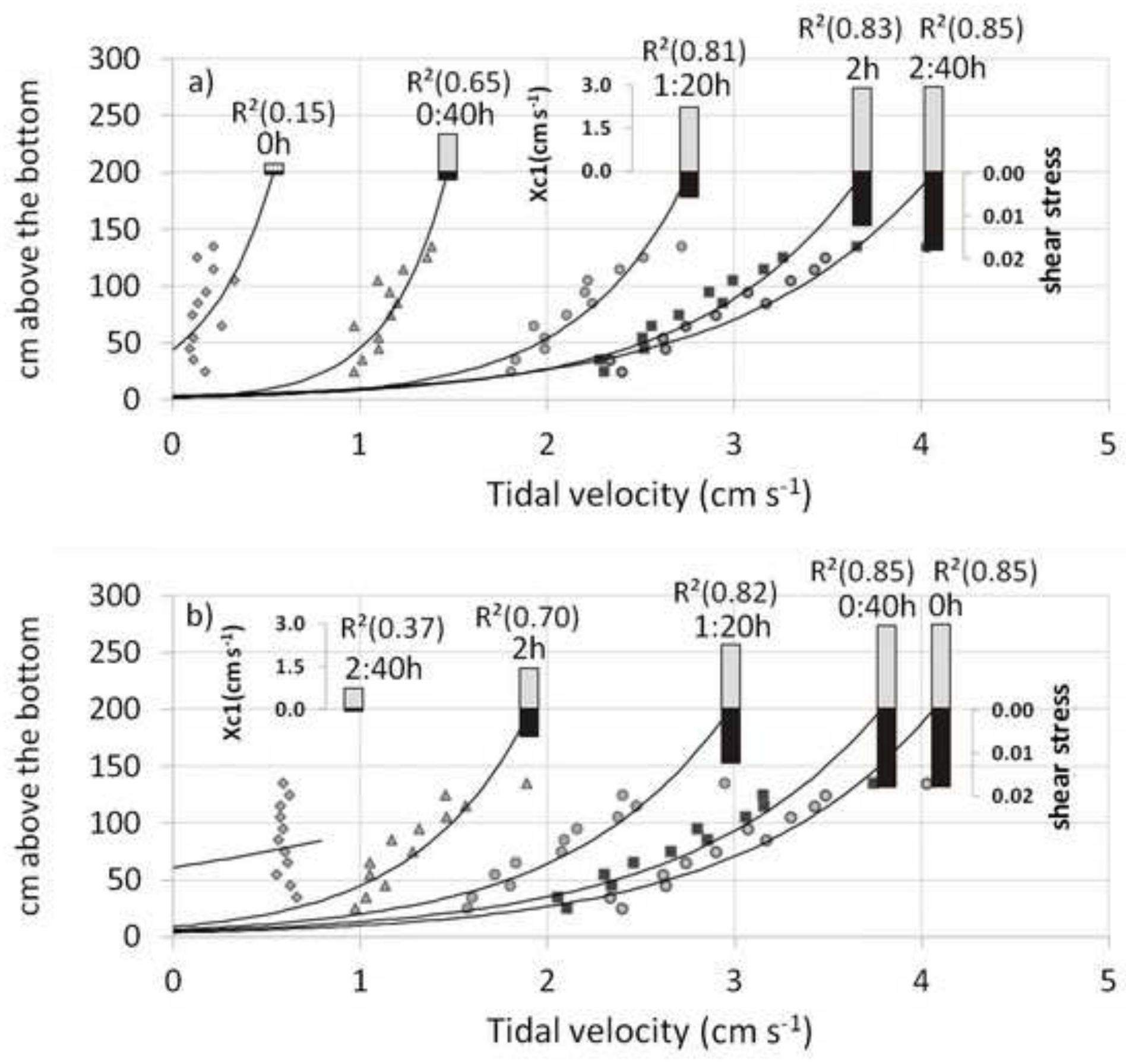
Click here to download high resolution image
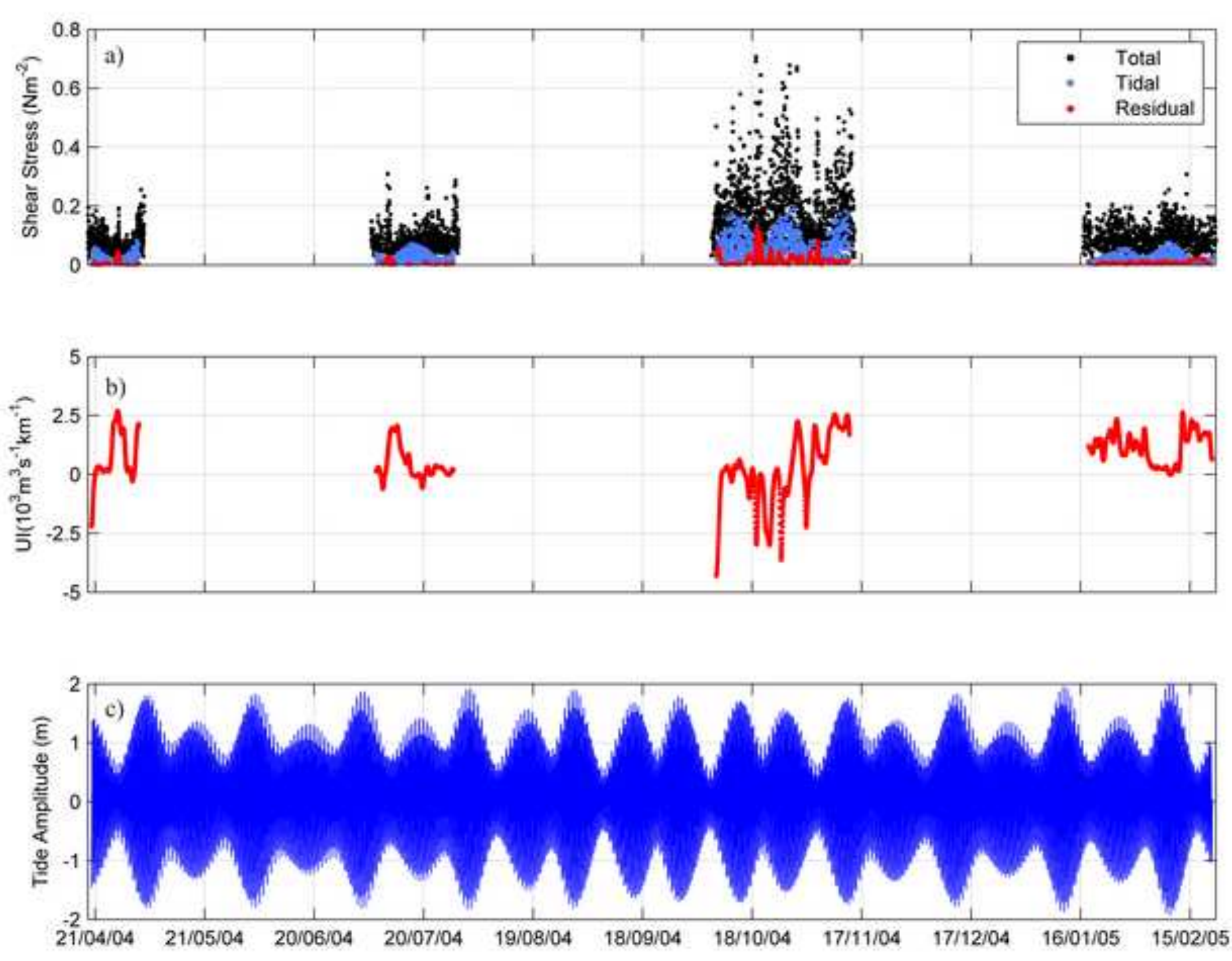


\section{Fure}

Click here to download high resolution image
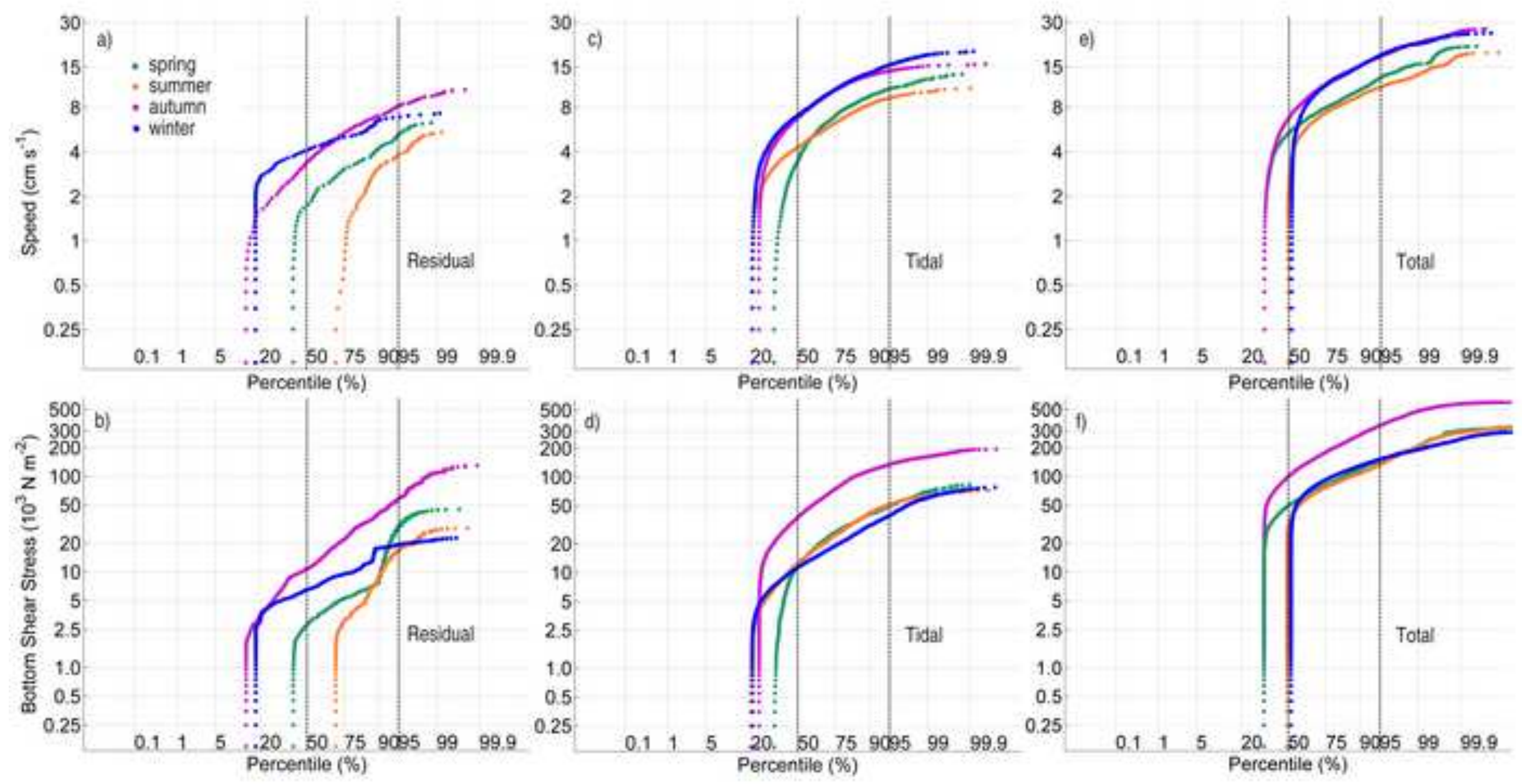


\section{Figure}

Click here to download high resolution image

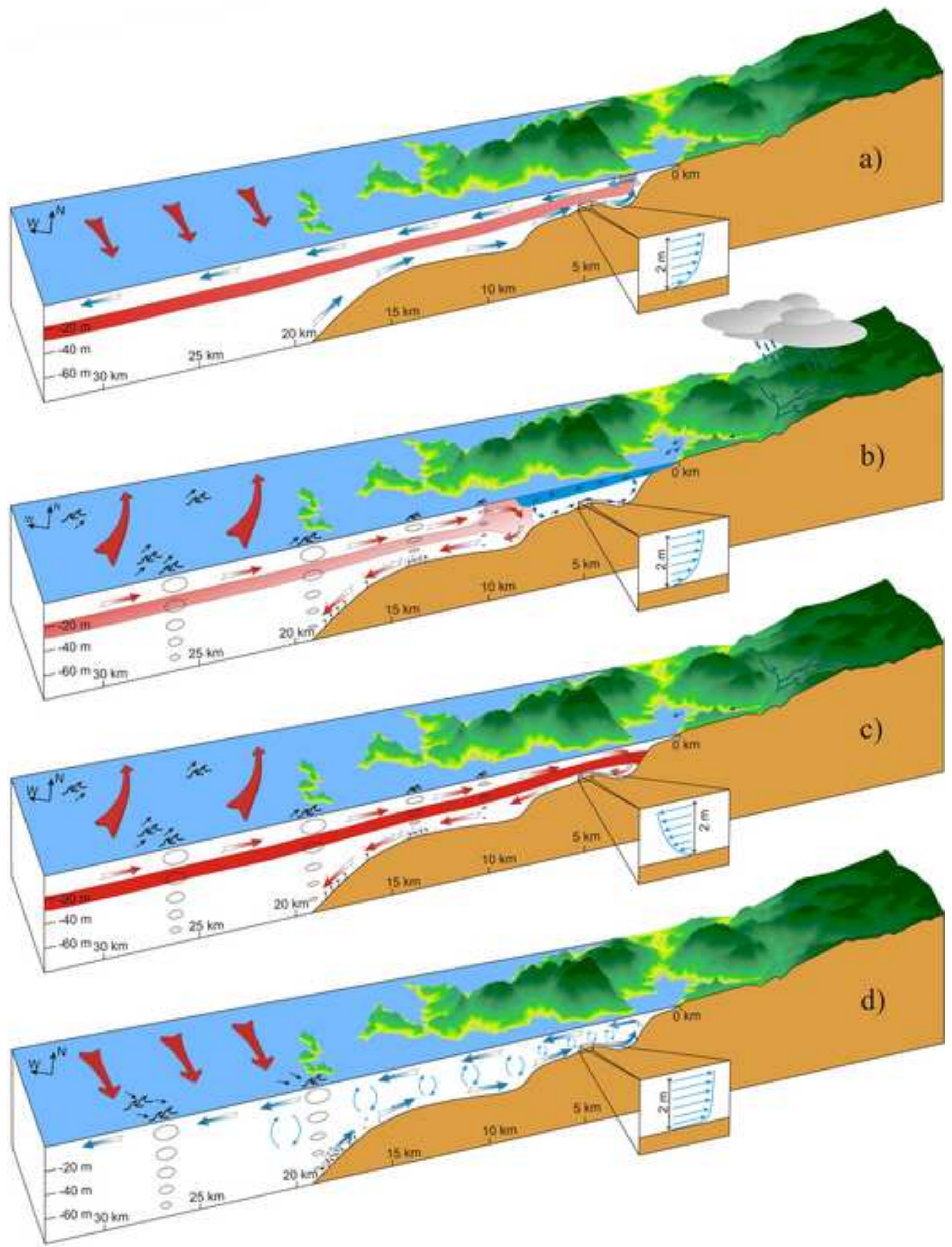


Click here to download Table: Tables_Villacieros-Robineau_et_al_CSR_23_may_2013.docx

\begin{tabular}{|c|c|c|c|c|}
\hline \multirow[t]{2}{*}{ Period } & \multirow[t]{2}{*}{$\begin{array}{c}\mathrm{N}^{\mathrm{o}} \\
\text { Harmonics }\end{array}$} & \multirow[t]{2}{*}{ Principal Harmonics } & \multicolumn{2}{|c|}{ Explained Variance } \\
\hline & & & Bandpass & Average data $10 \mathrm{~min}$ \\
\hline Annual & 49 & M2, S2, MKS2, NU2, N2 & $80.8 \%$ & $66.2 \%$ \\
\hline Summer & 6 & $\mathrm{M} 2, \mathrm{~S} 2, \mathrm{~K} 1, \mathrm{O} 1, \mathrm{M} 8, \mathrm{M} 6$ & $83.6 \%$ & $66.3 \%$ \\
\hline Autumn & 35 & M2, S2, N2, ALP1, K1, ETA2 & $84.9 \%$ & $76.7 \%$ \\
\hline Winter & 13 & M2, S2, N2, O1, NO1, M4 & $93.9 \%$ & $85.9 \%$ \\
\hline
\end{tabular}

Table 1. Principal harmonics obtained from the bandpass time series and explained variance for the bandpass time series and for the original time series averaged every 10minutes.

\begin{tabular}{lccc}
\hline \multicolumn{3}{c}{ Percentage of significative fits } \\
\hline & Residual & Tidal & Total \\
\hline Spring & $60.0 \%$ & $66.4 \%$ & $72.5 \%$ \\
Summer & $30.2 \%$ & $80.4 \%$ & $52.3 \%$ \\
Autumn & $86.2 \%$ & $75.6 \%$ & $74.5 \%$ \\
Winter & $82.0 \%$ & $79.1 \%$ & $47.1 \%$ \\
\hline All periods & $64.5 \%$ & $75.4 \%$ & $61.6 \%$ \\
\hline
\end{tabular}

Table 2. Percentage of significant fits in each period and in the whole of them for the residual and tidal currents. 
Residual

\begin{tabular}{|c|c|c|c|c|c|c|}
\hline \multirow[b]{2}{*}{ Percentile } & \multicolumn{2}{|c|}{ Current speed $1 \mathrm{mab}\left(\mathrm{cm} \mathrm{s}^{-1}\right)$} & \multicolumn{2}{|c|}{ Shear Stress $\left(\mathrm{N} \mathrm{m}^{-2}\right)$} & \multicolumn{2}{|c|}{ Shear Velocity $\left(\mathrm{cm} \mathrm{s}^{-1}\right)$} \\
\hline & $50 \%$ & $95 \%$ & $50 \%$ & $95 \%$ & $50 \%$ & $95 \%$ \\
\hline Spring & 1.7 & 5.2 & 0.003 & 0.033 & 0.17 & 0.57 \\
\hline Summer & 0.0 & 3.8 & 0.000 & 0.019 & 0.00 & 0.43 \\
\hline Autumn & 3.3 & 8.0 & 0.011 & 0.059 & 0.33 & 0.76 \\
\hline Winter & 4.1 & 6.7 & 0.006 & 0.019 & 0.25 & 0.43 \\
\hline
\end{tabular}

Table 3. Residual mean regime values for current speed (left), bottom shear stress (center) and shear velocity (right) for percentiles 50\% and 95\% for each sampling period.

Tidal

\begin{tabular}{|c|c|c|c|c|c|c|}
\hline \multirow[b]{2}{*}{ Percentile } & \multicolumn{2}{|c|}{ Current speed $1 \mathrm{mab}\left(\mathrm{cm} \mathrm{s}^{-1}\right)$} & \multicolumn{2}{|c|}{ Shear Stress $\left(\mathrm{N} \mathrm{m}^{-2}\right)$} & \multicolumn{2}{|c|}{ Shear Velocity $\left(\mathrm{cm} \mathrm{s}^{-1}\right)$} \\
\hline & $50 \%$ & $95 \%$ & $50 \%$ & $95 \%$ & $50 \%$ & $95 \%$ \\
\hline Spring & 3.4 & 10.8 & 0.012 & 0.049 & 0.35 & 0.69 \\
\hline Summer & 4.3 & 9.1 & 0.013 & 0.051 & 0.35 & 0.70 \\
\hline Autumn & 6.7 & 13.9 & 0.038 & 0.132 & 0.61 & 1.13 \\
\hline Winter & 7.0 & 15.1 & 0.011 & 0.039 & 0.33 & 0.62 \\
\hline
\end{tabular}

Table 4. Tidal mean regime values for current speed (left), bottom shear stress (center) and shear velocity (right) for percentiles $50 \%$ and $95 \%$ for each sampling period.

Total

\begin{tabular}{|c|c|c|c|c|c|c|}
\hline & \multicolumn{2}{|c|}{ Current speed $1 \mathrm{mab}\left(\mathrm{cm} \mathrm{s}^{-1}\right)$} & \multicolumn{2}{|c|}{ Shear Stress $\left(\mathrm{N} \mathrm{m}^{-2}\right)$} & \multicolumn{2}{|c|}{ Shear Velocity $\left(\mathrm{cm} \mathrm{s}^{-1}\right)$} \\
\hline Percentile & $50 \%$ & $95 \%$ & $50 \%$ & $95 \%$ & $50 \%$ & $95 \%$ \\
\hline Spring & 5.3 & 12.6 & 0.048 & 0.148 & 0.68 & 1.20 \\
\hline Summer & 1.4 & 10.9 & 0.017 & 0.134 & 0.41 & 1.14 \\
\hline Autumn & 6.5 & 17.5 & 0.098 & 0.336 & 0.98 & 1.81 \\
\hline Winter & 1.9 & 18.0 & 0.000 & 0.149 & 0.00 & 1.20 \\
\hline
\end{tabular}

Table 5. Total mean regime values for current speed (left), bottom shear stress (center) and shear velocity (right) for percentiles 50\% and 95\% for each sampling period. 


\begin{tabular}{cccccc}
\hline Cases & EOF & Percent & $\begin{array}{c}\text { UI } \\
\text { Silleiro }\end{array}$ & Currents & $\mathrm{T}^{\mathrm{a}}$ Gradient \\
\hline \multirow{3}{*}{ All } & Mode 1 & 55.5 & 0.6 & 0.6 & 0.4 \\
& Mode 2 & 28 & -0.4 & -0.2 & 0.9 \\
& Mode 3 & 16.5 & -0.7 & 0.7 & -0.1 \\
\hline \multirow{2}{*}{ Low Runoff } & Mode 1 & 68 & 0.6 & 0.6 & 0.6 \\
$<18 \mathrm{~m}^{3} \cdot \mathrm{s}^{-1}$ & Mode 2 & 18 & 0.8 & -0.6 & -0.1 \\
& Mode 3 & 14 & -0.3 & -0.5 & 0.8 \\
\hline \multirow{2}{*}{ High Runoff } & Mode 1 & 50 & 0.7 & 0.6 & 0.4 \\
$>=18 \mathrm{~m}^{3} \cdot \mathrm{s}^{-1}$ & Mode 2 & 30 & -0.1 & -0.4 & 0.9 \\
& Mode 3 & 20 & 0.7 & -0.6 & -0.2 \\
\hline \multirow{2}{*}{ Downwelling } & Mode 1 & 44 & 0.7 & 0.6 & 0.3 \\
UI $<=0$ & Mode 2 & 33 & 0.0 & -0.5 & 0.9 \\
& Mode 3 & 23 & 0.7 & -0.6 & -0.3 \\
\hline \multirow{2}{*}{ Upwelling } & Mode 1 & 61 & 0.6 & 0.5 & 0.6 \\
UI $>0$ & Mode 2 & 25 & -0.3 & 0.9 & -0.4 \\
& Mode 3 & 14 & 0.7 & 0.0 & -0.7 \\
\hline
\end{tabular}

Table 6. EOF analyses results. a) All cases d) Cases with high runoff $<18 \mathrm{~m}^{3} \mathrm{~s}^{-1}$. c) Cases with low runoff $>18 \mathrm{~m}^{3} \mathrm{~s}^{-1}$. d) Downwelling cases (UI < $<$ ) with high runoff and. e) Upwelling cases (UI >0) with high runoff and. 
Exceedance percentage for agregates thresholds

\begin{tabular}{lccc}
\hline & Residual & Tidal & Total \\
\hline Spring & $7.3 \%$ & $39.4 \%$ & $65.9 \%$ \\
Summer & $4.6 \%$ & $38.3 \%$ & $50.4 \%$ \\
Autumn & $35.3 \%$ & $70.2 \%$ & $66.2 \%$ \\
Winter & $7.8 \%$ & $30.8 \%$ & $47.2 \%$ \\
\hline
\end{tabular}

Exceedance percentage for fluffs thresholds

\begin{tabular}{lccc}
\hline & Residual & Tidal & Total \\
\hline Spring & $0.0 \%$ & $0.3 \%$ & $25.7 \%$ \\
Summer & $0.0 \%$ & $0.0 \%$ & $22.2 \%$ \\
Autumn & $2.3 \%$ & $21.2 \%$ & $57.8 \%$ \\
Winter & $0.0 \%$ & $0.0 \%$ & $31.5 \%$ \\
\hline
\end{tabular}

Table 7. Percentage of time in which the bottom shear stress, residual, tidal or total, exceeds the threshold for the initiation of movement for aggregates (left) and for fluffs (right), for each sampling period. 